\title{
31. NEOGENE BENTHIC FORAMINIFERS FROM DSDP LEG 42A, MEDITERRANEAN SEA
}

\author{
Ramil Wright, Beloit College, Beloit, Wisconsin ${ }^{1}$
}

\begin{abstract}
Benthic foraminifers from Neogene strata (Burdigalian-Pleistocene) are described and illustrated. Brief taxonomic and distributional notes, both stratigraphic and geographic, are given for the more common and paleoecologically interesting species.
\end{abstract}

\section{INTRODUCTION}

Numerous studies of the Neogene benthic foraminifers of the circum-Mediterranean area have been conducted but it was only with the advent of deep-sea drilling that it became possible to examine the benthic faunas of the Neogene strata of the central Mediterranean basins. The taxonomic and distributional notes presented here represent a preliminary attempt to gain a better understanding of these deep basins. A paleoecological interpretation of some of the foraminifers described here is given in Cita et al. and Wright in this volume.

\section{RESULTS AND DISCUSSION}

Specimens were examined from 211 samples taken from eight drill sites (Figure 1). Because of space limitations those taxa which occur only in trace quantities are not included in this listing. The following are taxa which appeared in such rare amounts (1 to 6 specimens out of 10,000 plus) that they were not cited: Cornuspira, Ehrenbergina, Elphidium, Fissurina, Lenticulina, Nodosaria, Oolina, Parafissurina, Patellina, Robertina, and various Miliolidae. Illustrations are given only of those species which are unusually abundant and/or paleoecologically significant and/or exhibit considerable morphological variation.

The illustrated specimens show that those found in Miocene and Pliocene strata exhibit considerable diagenetic alteration of the test walls.

It is interesting to note the presence of some species in the Mio-Pliocene strata of the Mediterranean drill sites which are well known in deep cold water of the World Ocean but are absent or very rare in the Quaternary strata and Recent sediments of the Mediterranean cores. These species are: Cibicidoides bradyi, C. kullenbergi, C. robertsonianus, Eponides polius, Nuttallides rusosus convexus, $N$. umboniferus, Osangularia culter and Trifarina angulosa pauperata. The restricted circulation patterns caused by the formation of the Gilbralter threshold seems to be the cause of the elimination of these cold, deep water species.

\footnotetext{
${ }^{1}$ Present address: Department of Geology, Florida State University, Tallahassee, Florida
}

The taxonomic approach followed in this paper is a broad one in which considerable variation is allowed in the species concept.

The synonomy for each species is abbreviated to save space and consists of the original reference plus only those additional references which are necessary to clarify the concept of the species. If holotype or topotype material was examined in the course of this investigation, the designation V.h. (Vidi holotypus) or V. t. (Vidi topotypus) is placed before the original reference.

The plate descriptions include the name of the species, the core location of the specimen, and the maximum dimension of the specimen.

For sending comparative material for study or for taking the time to examine and discuss the DSDP specimens, I acknowledge and thank L. Blanc-Vernet, M. Cita, S. D'Onofrio, W. Frerichs, M. MoncharmontZei, and A. Pujos-Lamy. Grateful appreciation is extended to E. Boltovskoy for his critical reading of the manuscript and for extensive and intensive discussion on benthic foraminifers. The photographs were taken on the ISI Supermini I SEM housed in the Geology Department, Florida State University.

\section{SYSTEMATIC PALEONTOLOGY}

\section{Ammonia beccarii (Linné)}

(Plate 1, Figures 1, 2)

V.t., Nautilus beccarii Linné, 1767, Syst. Nat., 12th ed., p. 1162.

There is a great deal of morphological variation present in this species. The concept of $A$. beccarii tepida is included here as several studies of Recent faunas both in the field (Ramanathan, 1975) and in culture (Schnitker, 1974) show these forms to intergrade continuously. This species occurs abundantly in some Messinian strata where it appears to be in situ (Sites 372 and 376) and also occurs as rare displaced specimens in other stratigraphic intervals. The specimens at Site 372 are less ornamented and lack the limbate sutures of those occurring at Site 376.

\section{Anomalina cicatricosa Schwager}

Anomalina cicatricosa Schwager, 1866, Novara Exped., Geol. Theil, v. 2 , no. 2 , p. 260 , pl.7, fig. 4,108 .

This species occurs only rarely in the Quaternary of Site 377 and the Serravallian of Site 372.

\section{Anomalinoides badensis (d'Orbigny)}

(Plate 1, Figures 3,4)

V.t., 1846, Foram. Foss. Bassin Tert. Vienne, p. 71, pl. 9, fig. 1-3.

The specimens are also similar to Truncatulina grosserugosa Gümbel described from the Nummulite limestone of Germany. This 


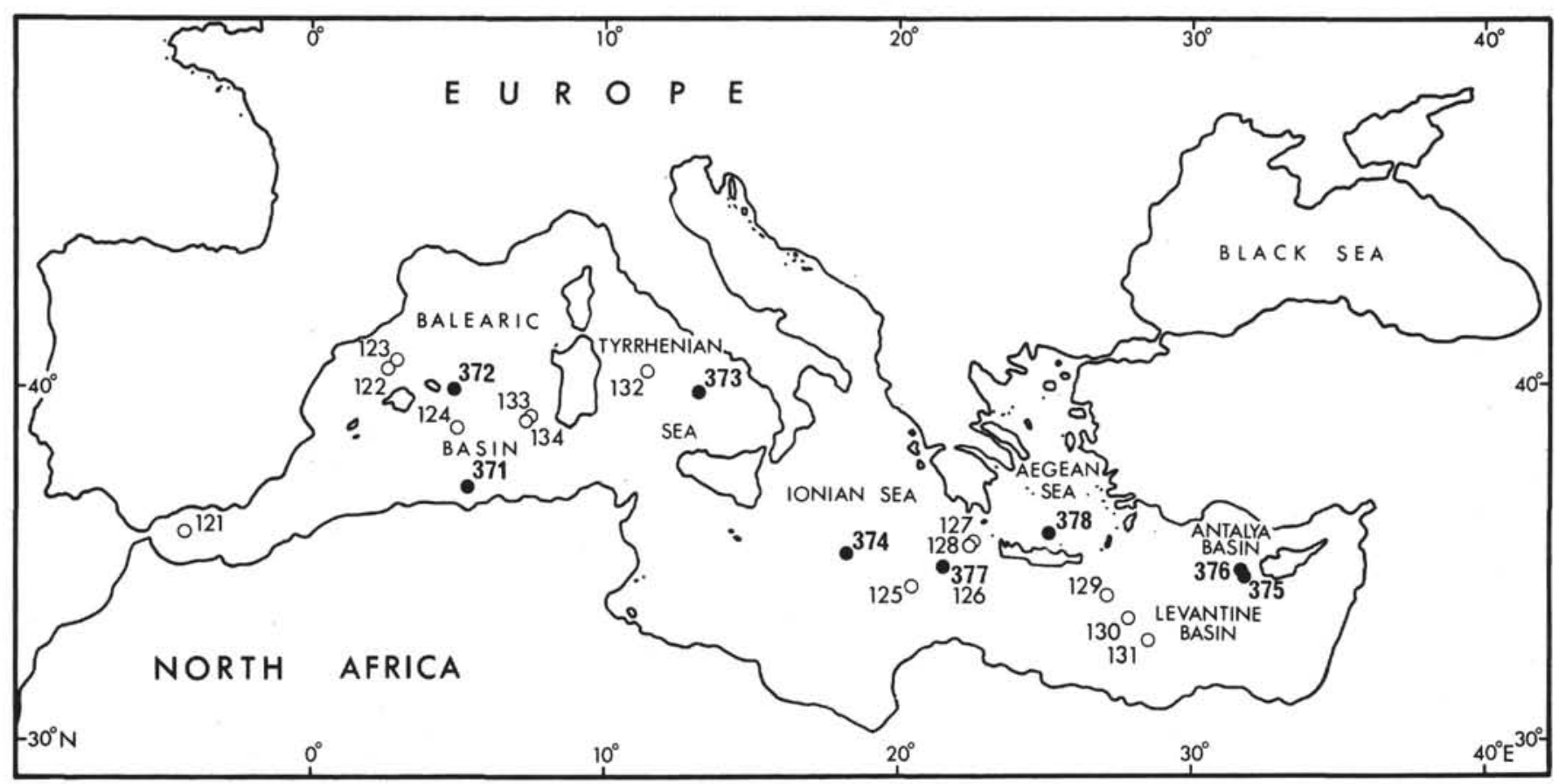

Figure 1. Location of drillsites, DSDP Leg $42 \mathrm{~A}$ in relation to those drilled on Leg 13.

species occurs as a rare but persistent element in the Neogene of the western Mediterranean.

\section{Anomalinoides flinti (Cushman)}

(Plate 1, Figures 5,6)

Anomalina flinti Cushman, 1936, Cushman Lab. Foram. Res., Contrib., v. 12 , pt. 3 , p. 68 , pl. 12, fig. $12,13$.

This species is found only at Site 372 in the western Mediterranean.

\section{Anomalinoides pseudogrosserugosa (Colom)}

(Plate 1, Figures 7, 8)

Anomalina pseudogrosserugosa Colom, 1945, Rev. Soc. Espa. Hist. Nat., Bol., v. 43 , p. 290 , pl. 31 , fig. 19-30.

This species was described originally from the Burdigalian or Mallorca and occurs abundantly in the Quaternary strata of Site 372 where the specimens are more compressed than those of Colom.

\section{Anomalinoides rotula (d'Orbigny)}

Anomalina rotula d'Orbigny, 1846, Foram. Foss. Bassin Tert. Vienne, p. 172 , pl. 9 , fig. 10-12.

This species occurs only at Site 376 in the eastern Mediterranean.

\section{Articulina tubulosa (Seguenza)}

(Plate 1, Figures 9, 10)

Quinqueloculina tubulosa Seguenza, 1862, Accad. Gioenia Sci. Nat. Catania, Atti, ser. 2, v. 18, p. 119, pl. 2, fig. 8.

The delicate, elongate uniserial chambers of the species are often broken off and specimens have been misidentified as Quinqueloculina. Careful examination of the aperture of these specimens reveals the break. The periphery of the quinqueloculine portion varies from rounded to angular. This species is a frequent element in Quaternary assemblages and is very rare below the uppermost Pliocene strata.

\section{Asterigerinata mamilla (Williamson)}

(Plate 1, Figure 11)

Rotalina mamilla Williamson, 1858, Recent Foraminifera Gt. Britain, Ray Soc., p. 54, pl. 4, fig. 109-111.

This species is uncommon in the Mediterranean cores and is associated with displaced faunas.

\section{Astrononion umbilicatulum Uchio \\ (Plate 1, Figure 12)}

Astrononion umbilicatulum Uchio, 1952, J. Japan Assoc. Petrol. Tech., v. 17 , p. 36 , fig. 1.
The Mediterranean forms of this species which was originally described from the lower Pleistocene of Japan and also found in Neogene strata of DSDP sites in the Indian Ocean, may be synonymous with $A$. stelligerum (d'Orbigny) which has been identified from the Bay of Naples. The umbilical covering is greatly reduced in the specimens from the cores as compared to that in A. stelligerium and resembles the Asian species in this regard.

\section{Bigenerina nodosaria d'Orbigny}

Bigenerina nodosaria d’Orbigny, 1826, Ann. Sci. Nat., sér 1, v. 7, p. 261, pl. 11, fig. 9-12,-modles no. 57. gstx-this species is rare at most sites.

\section{Bolivina alata Seguenza \\ (Plate 1, Figure 13)}

V.t., 1862, Accad. Gioenia, Sci. Nat. Catania, Atti, ser. 2, v. 18, p. 115 , pl. 2, fig. 5 .

This species is a sporadic element in all strata from all portions of the Mediterranean.

\section{Bolivina albatrossi Cushman \\ (Plate 1, Figures 14, 15)}

Bolivina albatrossi Cushman, 1922, U.S. Nat. Mus., Bull. no. 104, p. 31 , pl. 6, fig. 4 .

This species is characterized by reticulate sutures in the early chambers and is found only at Sites 372 and 378.

\section{Bolivina arta Macfayden}

Bolivina arta Macfayden, 1930, Miocene Foram. Clysmic Area, Egypt. Geol. Surv., p. 58, pl. 4, fig. 21.

This species, originally described from the Miocene of Egypt, is found in samples as young as the Quaternary in both the eastern and western Mediterranean drillsites.

\section{Bolivina beyrichi Reuss}

V.t., 1851, Deutsch Geol. Ges., Zeitschr., v. 3, p. 83, pl. 6, fig. 51.

This species occurs only in Tortonian strata of Site 372 and as reworked specimens in the Messinian sediments of Site 376.

\section{Bolivina catanensis Seguenza}

(Plate 1, Figure 16, 17)

V.t., 1862, Accad. Gioenia Sci. Nat. Catania, Atti, ser. 2, v. 18, p. 29 , pl. 2, fig. 3. 
This species is much more common in the western than in the eastern Mediterranean.

\section{Bolivina compacta Sidebottom}

(Plate 1, Figures 18, 19)

Bolivina robusta Brady var. compacta Sidebottom, 1905, Manchester Lit. Philos. Soc., Mem. Proc., v. 49 , no. 5 , p. 15 , pl. 3 , fig. 7.

This species is very common in the Mediterranean drillsites. The angle made by the sutures with the long axis varies between $60-90^{\circ}$. It may be confused with smoother forms of $B$. variablis but is more punctate and has sutures which are less depressed and, as a rule, not quite as inclined. B. paula Cushman and Cahill may be a junior synonym of this species.

\section{Bolivina dilatata Reuss}

(Plate 1, Figure 20)

V.t., 1850, K. Akad. Wiss. Wien, Math. Nat. Kl., Denkschr., v. 1, p. 381 , pl. 48 , fig. 15.

Topotypes of this species from the Vienna Basin exhibit well developed sigmoid sutures. This is a well known Neogene species from the circum-Mediterranean area. Specimens described as $B$. goesii Cushman by Parker (1954) from the northeast Gulf of Mexico are very similar to this species.

\section{Bolivina globulosa Cushman}

(Plate 2, Figure 1)

Bolivina globulosa Cushman, 1933, Cushman Lab. Foram. Res., Contrib., v. 9 , pt. 4 , p. 80 , pl. 8 , fig. 9.

This species, originally described from abyssal depths in the tropical Pacific may be isomorphic with the bathyal Gulf of Mexico species B. lowmani Phleger and Parker.

\section{Bolivina hebes Macfayden}

(Plate 2, Figure 2)

Bolivina hebes Macfayden, 1930, Miocene Foram. Clysmic Area, Egypt. Geol. Surv., p. 59, pl. 2, fig. 5.

This is a stout species with only 5-8 pairs of chambers which are not very distinct. The periphery is rounded and the surface rough.

\section{Bolivina incrassata Reuss}

Bolivina incrassata Reuss, 1951, Naturw. Abh., v. 4, no. 1, p. 45, pl. 5 , fig. 13.

The Mediterranean drillsite specimens differ from the types in having slightly less inclined sutures. This species may be synonymous with $B$. antigua d'Orbigny. Specimens are found only in Miocene strata of Site 372 .

\section{Bolivina parvula diNapoli}

(Plate 2, Figures 3, 4)

V.h., 1952, Riv. Ital. Pal. Strat., v. 58, no. 3, p. 99, pl. 5, fig. 11.

This species is similar to and could be confused with $B$. catanensis but has a less acute periphery and exhibits uniformily curved sutures.

\section{Bolivina placentina Zanmatti, 1957}

(Plate 2, Figure 5)

Bolivina placentina Zanmatti, 1957, Riv. Ital. Pal. Strat., v. 63, no. 4, p. 252 , fig. 6 .

This species is found only rarely in Messinian strata at Site 372 .

\section{Bolivina plicatella mera Cushman and Ponton}

Bolivina plicatella mera Cushman and Ponton, 1932, Fla. State Geol. Surv., Bull., no. 9 , p. 82 , pl. 12, fig. 4 .

This species occurs only in Messinian strata of Site 376.

\section{Bolivina pseudoplicata Heron-Allen and Earland}

$$
\text { (Plate 2, Figures 6, 7) }
$$

Bolivina pseudoplicata Heron-Allen and Earland, 1930 J. Roy. Micr. Soc., ser. 3, v. 50 , p. 81 , pl. 3, fig. $36-40$.

This is a ubiquitous species in Recent waters and is well known in the Mediterranean. The strength of the plications is variable and those with weak ornamentation can be confused with $B$. variablis.

\section{Bolivina pseudopunctata Höglund}

Bolivina pseudopunctata Höglund, 1947, Uppsala, Univ., Zool. Bidrag. v. 26 , p. 273 , pl. 24 , fig. 5 ; pl. 32 , fig. 23,24 ; p. 268 , textfig. 280-281.

This species occurs rarely in the Mediterranean drillsites. It is characterized by a concentration of pores on the lower half of the chambers. B. seminuda Cushman is similar in form but is more coarsely perforate.

\section{Bolivina reticulata Hantken}

(Plate 2, Figures 8-10)

Bolivina reticulata Hantken, 1875, K. Ungar. Geol. Anst., Mitt. Jahrb., v. 4 , no. 1 , p. 65 , pl. 15 , fig. 6 .

This species and its numerous variants is taxonomically confusing and requires detailed study. The specimens of the Mediterranean drillsites display a great deal of variation in shape and ornamentation. Those most similar to the poorly figured type of Hantken possess a clear strong reticulation which obscures the sutures (Plate 1, Figure 8 ). Some specimens are more elongate and have limbate sutures and less pronounced reticulation (Plate 1, Figure 9). Others are squat, broad forms (Plate 1, Figure 10). The forms here called $B$. reticulata may include such species as $B$. algeriana Glaçon, Magné and Muraour, $B$. anastomosa Finlay, B. coelata Cushman, B. fastiga dertonensis Gianotti, B. heineae Galloway and Heminway, B. leonardi Accordi and Selmi, B. peregrina Schwager, B. scalprata retiformis Cushman, and $B$. subreticulata Parr. This species is common in the western Mediterranean drillsites in strata of early Pliocene age and older.

\section{Bolivina silvestrina Cushman}

(Plate 2, Figure 11)

Bolivina silvestrina Cushman, 1936, V.t., Cushman Lab. Foram. Res., Spec. Publ. no. 6, p. 56, pl. 8, fig. 5.

The Mediterranean drillsite specimens are slightly more twisted than the topotypes of this species from the Pliocene of Italy.

\section{Bolivina cf. B. simpsoni Heron-Allen and Earland} (Plate 2, Figure 12)

Bolivina cf. B. simpsoni Heron-Allen and Earland, 1915, Zool. Soc. London, Trans., v. 20 , pt. 17 , p. 648 , pl. 49 , fig. 18-35.

The drillsite specimens are much smaller and less spinose than this variable species; their designation is doubtful. The specimens also resemble $B$. dentellata Tavani which was originally described from the Tortonian of Italy.

\section{Bolivina spathulata (Williamson)}

(Plate 2, Figures 13, 14)

Textularia variablis var. spathulata Williamson, 1858 , Rec. Foram. Gt. Britain, Ray Soc., p. 76, pl. 6, fig. 164, 165.

This species is compressed, with an acute periphery, almost keeled, and slightly depressed, curved, limbate sutures which form an angle of about $45^{\circ}$ with the long axis of the test. This species is morphologically similar to $B$. catanensis and the two species have often been lumped together under one of these designations. $B$. spathulata has more strongly tapered lateral margins than does $B$. catanensis. This species may also have been identified as $B$. dilatata by various authors although it lacks the sigmoid sutures of the d'Orbigny species. Another similar species is $B$. lanceolata diNapoli from the Calabrian of Italy whose holotype has straighter sutures.

\section{Bolivina subaenariensis Cushman}

(Plate 2, Figure 5)

Bolivina subaerariensis Cushman, 1922, U.S. Nat. Mus. Bull. no. 104, p. 46 , pl. 7 , fig. 6 .

This species is a persistent but infrequent member of assemblages in both the eastern and western Mediterranean sites.

\section{Bolivina sublobata Cushman, 1936}

(Plate 2, Figure 16)

Bolivina sublobata Cushman, 1936, Cushman Lab. Foram. Res., Spec. Publ. no. 6, p. 52, pl. 7, fig. 16.

This species, originally described from the Oligocene of Victoria, Australia, is very similar to and may be conspecific with $B$. pomposa Coryell and Mossman from the Pliocene of Panama. It has a more 
lobate periphery than $B$. usensis Conato from the upper Pliocene of Italy and has a rougher surface and is more beaded and reticulate than the holotypes of $B$. villalverniensis Martinis from the lower Pliocene of northern Italy. It occurs only in the Miocene strata of Site 372

\section{Bolivina subspinescens Cushman}

Bolivina subspinescens Cushman, 1932, U.S. Nat. Mus. Bull. no. 104 p. 48 , pl. 7 , fig. 5 .

This species is found as isolated specimens in strata of all ages in both eastern and western drillsites of the Mediterranean.

\section{Bolivina cf. B. thalmani Renz}

(Plate 2, Figures 17, 18)

Bolivina cf. thalmani Renz, 1948, Geol. Soc. Amer., Mem., no. 32, p. 120 , pl. 12, fig. 13 .

The Mediterranean drillsite specimens are more quadrate than those of Renz and exhibit a more lobate periphery. They are gradational with $B$. sublobata.

\section{Bolivina variablis (Williamson)}

(Plate 2, Figures 19, 20)

Textularia variablis Williamson, 1858, Rec. Foram. Gt. Britain. Ray Soc., p. 76, pl. 6, fig. 162, 163.

Forms of this species in which the "conspicuous central groove" is very pronounced begin to look like $B$. pseudoplicata whereas the smoother varieties approach $B$. compacta. This is a common species, especially at Site 372 .

\section{Bolivinita concavomeonia Poag}

(Plate 2, Figure 21)

Bolivinita concavomeonia Poag, 1966, Micropaleontology, v. 12, no. 4, p. 406, pl. 3, fig. 38, 39.

This rare species is found only in the Messinian at Sites 375 and 376 but throughout the Neogene at Site 372.

\section{Bolivinopsis compta Finlay}

(Plate 3, Figures 1, 2)

Bolivinopsis compta Finlay, 1947, New Zeal. J. Sci. Technol., sec. B. v. 28 , no. 5 , p. 262 , pl. 1 , fig. 8-12.

This species was found only at Site 372 in Cores 9 and 10 (Tortonian/Serravallian) where it is abundant.

\section{Bulimina aculeata d'Orbigny}

(Plate 3, Figure 3)

Bulimina aculeata d'Orbigny, 1826, Ann. Sci. Nat., sér. 1, v. 7, p. 269; Parker, Jones and Brady, 1871, Ann. Mag. Nat. Hist., ser. 4, v. 8, pl. 11, fig. 128; Fornasini, 1902, Accad. Sci. Bologna. Mem., ser. 5 , v. 9 , p. 153 , fig. 4 .

This frequently occurring species is easily distinguished from $B$. marginata by its flaring spines. It may be conspecific with $B$. elongata subulata Cushman and Parker, both of which were described from the Miocene of the Vienna Basun. B. aculeata has more clearly defined spines but the variation of the two species appears to overlap.

\section{Bulimina affecta Cushman and Stainforth}

(Plate 3, Figure 4)

Bulimina affecta Cushman and Stainforth, 1951, J. Paleontol., v. 25, no. 2 , p. 154 , pl. 26 , fig. 40,41 .

This smooth buliminid has less inflated chambers than $B$. elongata and fewer whorls than $B$. thanetensis. It is similar to the small non-costate specimens of $\boldsymbol{B}$. translucens Parker. It is found only at Site 372 in the western Mediterranean.

\section{Bulimina alazanensis Cushman}

(Plate 3, Figures 5, 6)

Bulimina alazanesis Cushman,1927, J. Paleontol., v. 1, p. 161, pl. 25, fig. 4.

This frequently occurring species may be a junior synonym of $B$. rostrata Brady but does not have costae completely covering the last chambers as does Brady's species. The costae of the Mediterranean specimens are not as strong as those of Cushman's figured types and the specimens described here may only be robust examples of $B$. semicostata.

\section{Bulimina barbata Cushman}

Bulimina barbata Cushman, 1927, Scripps Inst. Oceanogr., Bull., Tech. Ser., v. 1, p. 151, pl. 2, fig. 11.

This species is very rare in the cores, occurring in only one Burdigalian sample at Site 372 . It may be a variant of $B$. inflata although it has less ornamentation, longer chambers, weaker spines, no costae, and a more acuminate shape.

\section{Bulimina buchiana d'Orbigny}

(Plate 3, Figure 7)

Bulimina buchiana d'Orbigny, 1846, Foram. Foss. Bassin Tert. Vienne, p. 186, pl. 11, fig. 15-18.

The robust costate buliminids, B. buchiana, B. costata, B. inflata and $B$. striata, are taxonomically confusing. Some authors have kept the four species distinct (Fornasini, 1901) and others have considered them as the same species (Marks, 1951). B. buchiana is primarily distinguished from the others because the lower edge of the chamber is rounded.

\section{Bulimina costata d'Orbigny}

Bulimina costata d'Orbigny, 1852, Prodrome Paleontol. Strat. Univ. Animaux Mollus. Rayonnés, V. Masson, Paris, v. 3, p. 194; Fornasini, 1901, Boll. Soc. Geol. Ital., v. 20, p. 174, fig. 1.

This rare species has strong heavy costae which are often continuous from one chamber to the next. The base of the chambers is acute. The initial portion of the test is less acute than that of $B$. striata.

\section{Bulimina gibba Fornasini}

Bulimina gibba Fornasini, 1902, R. Accad. Sci. Ist. Bologna, Mem. Sci. Nat., ser. 5 , v. 9 , p. 378 , pl. O, fig. $32,34$.

This species occurs in only one Serravallian sample at Site 372 .

\section{Bulimina inflata Seguenza}

(Plate 3, Figures 8, 9)

V.t., 1862, Accad. Gioenia Sci. Nat. Catania, Atti, ser. 2, v. 18, p. 109 , pl. 1, fig. 10.

Topotypes of this species exhibit chambers whose lower margins are acute, crenulated, and covered by costae which begin at mid chamber and end in a short spine projecting below the chamber margin. The overall shape is squat compared to the other costate buliminids. This is the most common and widespread of the robust costate buliminids in the Mediterranean sites.

\section{Bulimina marginata d'Orbigny}

Bulimina marginata d’Orbigny, 1826, Ann. Sci. Nat., sér. 1, v. 1, p. 269 , pl. 12, fig. 10-12.

This species is rare and occurs primarily in displaced samples.

\section{Bulimina semicostata Nuttall}

(Plate 3, Figure 10)

Bulimina semicostata Nuttall, 1930, J. Pạleontol., v. 4, no. 3, p. 285, pl. 23, fig. 15, 16 .

The Mediterranean drillsite specimens are not as elongate as those figured by Nuttall and the overall form is like that of $B$. alazanensis but the costae are much weaker. The costae of the Mediterranean specimens begin at the base of the last chamber, a higher position than those on the figured types. This species may be a reduced or depauperate $B$. alazanensis. It is a frequent component in pre-Quaternary samples.

\section{Cassidulina crassa d'Orbigny}

(Plate 3, Figure 11, 12)

V.t., 1839, Voy. Amér. Mérid., Strasbourg, Levrault, v. 5, pt. 5, p. 56 , pl. 7 , fig. $18-20$.

D'Orbigny's figures are a poor representation of this common and ubiquitous species. Examination of material from Discovery Site 388 of Heron-Allen and Earland (1932) near the Malvinas (Falkland) Islands where d'Orbigny originally described the species reveals a greater degree of variation than indicated by d'Orbigny. Some of the Mediterranean drillsite specimens (Plate 3. Figure 12) 
are like the smaller forms described by Heron-Allen and Earland and referred to as $C$. crassa, forma minima by Boltovskoy (1959). Others (Plate 3, Figure 11) are similar in shape to the typical forms of d'Orbigny but are smaller.

\section{Cassidulina braziliensis Cushman}

Cassidulina braziliensis Cushman, 1922, U.S. Nat. Mus., Bull., no. 104 , p. 130 , pl. 25 , fig. 4,5 .

This species may be conspecific with $C$. crassa porrecta HeronAllen and Earland whose topotypes are similar to Cushman's description and figures.

\section{Cassidulina laevigata d'Orbigny}

(Plate 3, Figures 13, 14)

Cassibulina laevigata d’Orbigny, 1826 Ann. Sci. Nat., ser. 1, v. 1, p. 282 , pl. 15 , fig. $4,5$.

The acute periphery of this common species is quite variable and may become strongly carinate. The carinate form, $C$. carinata Silvestri, is included here with $C$. laevigata although most of the Mediterranean drillsite specimens are not strongly carinate.

\section{Cassidulina minuta Cushman}

(Plate 3, Figures 15, 16)

Cassidulina minuta Cushman 1933, Cushman Lab. Foram. Res. Contrib., v. 9, pt. 4, p. 92, pl. 10, fig. 3.

This common species is a variant of $C$. crassa, and exhibits a compressed test and subacute periphery. It differs from $C$. laevigata by having 4 chambers per whorl. The aperture is more elongate than that of $C$. crassa.

\section{Cassidulina subglobosa Brady}

(Plate 3, Figure 17)

Cassidulina subglobosa Brady, 1881, Quart. J. Micr. Sci., n. ser., v. 21, p. 60; 1884, Rept. Voy. Challenger, Zool., v. 9, pl. 54, fig. 17.

This species is a common component of most sites and stratigraphic intervals.

\section{Chilostomella oolina Schwager}

V.t., 1878, R. Com. Geol. Ital., Italy Uff. Geol., Boll., V. 9, p. 527, pl. 1, fig. 16.

The Mediterranean specimens are identical with topotypes of this species from the Tortonian of Sicily.

\section{Cibicides aknerianus (d'Orbigny)}

(Plate 3, Figure 18)

V.t., Rotalina aknerianus d'Orbigny, 1846, Foram. Foss. Bassin Tert. Vienne, p. 156, pl. 18, fig. 13-15.

This species occurs rarely in Site 372 .

\section{Cibicides austriacus (d'Orbigny)}

Anomalina austriaca d'Orbigny, 1846, Foram, Foss. Bassin Tert. Vienne, p. 172, pl. 10, fig. 4-9.

This species is most frequent in Messinian and lower Pliocene strata of the eastern Mediterranean.

\section{Cibicides lobatulus (Walker and Jacob)}

Nautilus lobatulus Walker and Jacob, 1798, Adams Essays, Kannmachers (ed.), p. 642, pl. 14, fig. 36.

This species is a frequent component of samples which show signs of downslope transport.

\section{Cibicides pachydermus (Rzehak)}

(Plate 3, Figures 19, 20)

Truncatulina pachyderma Rzehak, 1886, Naturf. Ver. Brunn, Verh. v. 24 , p. 87 , pl. 1 , fig. 5 .

This common and widespread species may have been referred to in the Mediterranean area as Cibicides aff. C. floridanus or C. pseudoungerianus but it lacks the distinct sutures and lobate periphery of the latter.

\section{Cibicides tenellus (Reuss)}

Truncatulina tenella Reuss, 1865, K. Akad. Wiss. Wien, Math. Naturw. Kl., v. 50, p. 477 , pl. 5, fig. 5 . ranean.

This species is confiend to the Messinian of the eastern Mediter-

\section{Cibicides variolatus (d'Orbigny)}

Anomalina variolata d'Orbigny, 1846, Foram. Foss. Bassin Tert. Vienne, p. 170, pl. 9, fig. 27-29.

This species is found only in the eastern Mediterranean.

\section{Cibicides wuellerstorfi (Schwager)}

(Plate 4, Figure 1)

Anomalina wuellerstorfi Schwager, 1866, Novara Exped., Geol. Theil, v. 2 , no. 2 , p. 258 , pl. 7 , fig. $105,107$.

This species exhibits a great deal of variation in the degree of perforation and curvature of the sutures. It occurs frequently at Site 372.

\section{Cibicidoides bradyi (Trauth)}

(Plate 4, fig. 2-4)

Truncatulina dutemplei Brady (non d'Orbigny), 1884, Rept. Voy. Challenger, Zool., v. 9, p. 665, pl. 95, fig. 5.

Truncatulina bradyi Trauth, 1918, K. Akad. Wiss. Wein, Math. Naturw. Kl., Denkschr., v. 95, p. 235.

This species, although known in Recent sediments outside the Mediterranean, is frequent only in pre-Quaternary strata of the Mediterranean drillsites.

\section{Cibicidoides kullenbergi Parker}

(Plate 4, Figures 5-7)

Cibicidoides kullenbergi Parker, 1953, Swedish Deep-Sea Exped., v. 7 , no. 1 , p. 49 , pl. 11 , fig. 7,8 .

This species, usually typical of water depths greater than 10001200 meters is biconvex with the involute side more convex than the evolute. There are 3 whorls, the last of which is composed of about 11 chambers. There is a narrow but distinct keel and flush, curved sutures. The umbilical area is filled with clear shell material.

\section{Cibicidoides cf. C. kullenbergi}

(Plate 4, Figure 8)

This form differs from $C$. kullenbergi in having only 7-9 chambers in the final whorl and a much less pronounced keel or none at all. The chamber shape and arrangement is also similar to that of $C$. robertsonianus. In all other respects however, it is clearly related to C. kullenbergi. It is not clear whether it is a separate species or merely a variant of the nominate species. Consequently, the two are kept separate here.

\section{Cibicidoides robertsonianus (Brady)}

(Plate 4, Figure 9)

Truncatulina robertsoniania Brady, 1881, Quart. Jour. Micr. Soc., v. 21, p. 65; 1884, Rept. Voy. Challenger, Zool., v. 9, p. 664, pl. 95, fig. 4.

Specimens of the Mediterranean drillsites usually have 9-12 chambers per whorl compared to the 13-14 described by Brady. Small and immature specimens of this deep-water species may be confused with $C$. bradyi but have almost radial sutures on the involute side in contrast to the oblique sutures of $C$. bradyi. Specimens are found only in Pliocene and older strata in the Mediterranean cores although the species is known in Recent deep-sea sediments outside the Mediterranean.

\section{Dentalina communis d'Orbigny}

Nodosaria (Dentalina) communis d'Orbigny, 1826, Ann. Sci. Nat., sér. 1, v. 7, p. 254.

This species is a rare but persistent component of many samples.

\section{Discorbis aff. D. columbiensis Cushman}

Discorbis aff. columbiensis Cushman, 1925, Cushman Lab. Foram. Res., Contrib., v. 1, p. 43, pl. 6, fig. 13

Specimens from the Mediterranean DSDP cores are more compressed than the ones figured by Cushman. After extensive study of this species, Lankford and Phleger (1973) suggested that it may be conspecific with $D$. globularis. 


\section{Discorbis globularis (d'Orbigny)}

Rosalina globularis d’Orbigny, 1826, Ann. Sci. Nat., sér. 1, v. 7, p. 271, pl. 13, fig. 1-4.

This species, like most of the discorbids in the core samples, is found only in displaced samples.

\section{Discorbis aff. D. obtusa (d'Orbigny)}

V.t., Rosalina obtusa d'Orbigny, 1846, Foram. Foss. Bassin Tert. Vienne, p. 179, pl. 11, fig. 4.

The Mediterranean specimens have raised limbate sutures on the evolute side and in this way differ from Vienna Basin topotype material.

\section{Discorbis parkerae Natland}

Discorbis parkerae Natland, 1931, Geol. Soc. Am. Mem., no. 43, pt. 4, p. 27, pl. 6, fig. 11.

\section{Discorbis rosacea (d'Orbigny)}

V.t., Rotalia rosacea d'Orbigny, 1826, Ann. Sci. Nat., sér. 1, v. 7, p. 272, modèles no. 35, 1839, Cuba, pl. 3, fig. 9-11.

\section{Eggerella bradyi (Cushman)}

(Plate 4, Figure 10)

Verneuilina bradyi Cushman, 1911, U.S. Nat. Mus. Bull., no. 71, p. 54, fig. 87.

This triserial finely agglutinate species might be confused with immature specimens of Karreriella bradyi whose mature stage is biserial. Phleger, Parker and Peirson (1953) reported that some E. bradyi have a short biserial stage and might be confused with Karreriella bradyi. These two species may often have been lumped together in specimen counts. This species is found in small numbers in many sites and stratigraphic intervals.

\section{Epistominella exigua (Brady)}

(Plate 4, Figures 11, 12)

Pulvinulina exigua Brady, 1884, Rept. Voy. Challenger, Zool., v. 9, p. 696, pl. 103, fig. 13, 14.

The Mediterranean drillsite specimens have a less lobate periphery than do the type figures. Brady's figures and description of the species are not particularly clear and the species has been broadly interpreted with the number of chambers varying from 5 to 6 and the periphery ranging from acute to rounded. The interpretation used here is broad and includes $P$. tangentialis Clodius with an acute margin and E. sandiegoensis Uchio with a rounded periphery.

\section{Eponides polius Phleger and Parker}

(Plate 4, Figures 13, 14)

Eponides polius Phleger and Parker, 1951, Geol. Soc. Amer., Mem. 46 , pt. 2 , p. 21 , pl. 11 , fig. 1,2 .

This species is easily confused with immature specimens of Gyroidina altiformis and with $G$. delicata and may be included here with speciment counts of these species.

\section{Eponides pusillus Parr \\ (Plate 4, Figures 15, 16)}

Eponides pusillus Parr, 1950, B.A.N.Z. Antarc. Res. Exped. 19291931, Repts., ser B, v. 5, pt. 6, p. 360 , pl. 14, fig. 16.

These specimens are identical to the figured types of Parr but also resemble specimens of E. turgidus Phleger and Parker from the Gulf of Mexico although they have a less convex spiral side. The Mediterranean specimens also resemble Pulvinulina geinitzi Clodius from the Oligocene-Miocene of Germany but do not possess the convex dorsal knob of that species. Epistominella levicula Resig is also morphologically similar. This species is abundant to common at every site.

\section{Eponides schreibersii (d’Orbigny)}

Rotalina schreibersii d’Orbigny, 1846, Foram. Foss. Bassin Tert. Vienne, p. 154, pl. 8, fig. 4-6.

This species is essentially restricted to the upper Miocene-lower Pliocene strata.

\section{Fursenkoina complanata (Egger)}

(Plate 4, Figure 17)

Virgulina schreibersiana Czjzek var. complanata Egger, 1893, Gazelle Exped., K. Bayer. Akad. Wiss., Math. Physik. Kl., Abh., v. 18, ser. 2, p. 292, pl. 8, fig. 91 , 92 .

This species occurs only in post-Langhian strata.

\section{Gavelinopsis praegeri (Heron-Allen and Earland)}

(Plate 4, Figure 18)

Discorbina praegeri Heron-Allen and Earland, 1913, Clare Is. Surv., Roy. Irish Acad. Proc., v. 31, sec. 3, p. 122, pl. 10, fig. 8-10.

This small species with a small umbilical plug, acute periphery, flush sutures, 5-6 chambers per whorl, a convex spiral side and flatter umbilical side is not very common in the core samples. It is probably displaced from shallow water zones.

\section{Glabratella pulvinata (Brady)}

Discorbina pulvinata Brady, 1884, Rept. Voy. Challenger, Zool., v. 9, p. 650 , pl. 88, fig. 10.

This easily recognized shallow water species is found in some of the displaced samples.

\section{Globobulimina affinis (d'Orbigny)}

Bulimina affinis d'Orbigny, 1839, Cuba, p. 105, pl. 2, fig. 25, 26.

The large ovate globobuliminids (G. affinis, $G$. auriculata, $G$. caudigera, G. ovata, G. ovula, and $G$. pupoides) are all quite similar and discrimination among them is difficult.

\section{Globobulimina aff. G. pseudospinescens (Emiliani)}

V.t. Bulimina pyrula d'Orbigny var. pseudospinescens Emiliani, 1949,

Riv. Ital. Pal. Strat., v. 55, no. 1, p. 9, pl. 2, fig. 24, 25.

The specimens in the Mediterranean cores have poorly developed and few spines and are not as robust as topotype specimens from Calabria, Sicily.

\section{Gyroidina altiformis Stewart and Stewart} (Plate 5, Figures 1-3)

Gyroidina soldanii d'Orbigny var. altiformis Stewart and Stewart, 1930, J. Paleontol., v. 4, no. 1, p. 67, pl. 9, fig. 2.

This species, with an acute periphery, open umbilicus, high test, $7-10$ chambers in the final whorl and approximately two whorls is distinguished from $G$. soldanii by its oblique spiral sutures.

\section{Gyroidina delicata Parker}

(Plate 5, Figure 4)

Gyroidina delicata Parker, 1958, Swedish Deep-Sea Exped., v. 8, no. 4, p. 265 , pl. 3, fig. 7-9.

This species is a small variant of $G$. altiformis although it is somewhat more compressed and has an umbilicus which is almost closed. The spiral side is not as indented along the sutures as is the test of $G$. altiformis.

\section{Gyroidina laevigata d'Orbigny}

Gyroidina laevigata d'Orbigny, 1826, Ann. Sci. Nat., sér. 1, v. 7, p. 278; Parker, Jones and Brady, 1871, Ann. Mag. Nat. Hist., ser. 4, v. 8 , pl. 12, fig. 150 .

This species is morphologically similar to G. lamarckiana but has 10-12 chambers per whorl and limbate sutures.

\section{Gyroidina lamarckiana (d'Orbigny)}

Rotalina lamarckiana d’Orbigny, 1839, Iles Canaries, p. 131, pl. 1, fig. 13-15.

This species is distinguished by its slightly compressed form and rounded periphery. It has radiate, slightly curved sutures, a closed umbilicus, 6 to 8 chambers in the final whorl and only 1 to $1-1 / 2$ whorls per test.

\section{Gyroidina orbicularis d'Orbigny}

(Plate 5, Figures 5, 6)

Gyroidina orbicularis d'Orbigny, 1826, Ann. Sci. Nat., sér. 1, v. 7, p. 278, modèles no. 13; Parker, Jones and Brady, 1865, Ann. Mag. Nat. Hist., v. 16, ser. 3, pl. 3, fig. 85 .

This species has radiate sutures, a sub-acute periphery, an umbili- 
cus which is almost closed, a compressed test, 6 to 10 chambers per whorl and 2-1/2 whorls per test. The chambers are not inflated.

\section{Gyroidina soldanii d'Orbigny}

(Plate 5, Figures 7-9)

Gyroidina soldanii d’Orbigny, 1826 Ann. Sci. Nat., sér. 1, v. 7, p. 278, modèles no. 36; d'Orbigny, 1846, Foram. Foss. Bassin Tert. Vienne, p. 155, pl. 8, fig. 10-12.

This species with its high chambers is distinguished from other similar Gyroidina by its radiate sutures, acutely rounded periphery, open umbilicus and 3 whorls per test.

\section{Gyroidina umbonata (Silvestri)}

(Plate 5, Figures 10, 11)

Rotalia soldanii d'Orbigny var. umbonata Silvestri, 1898, Accad.

Pont. Nuovi Lincei, Mem., v. 15, p. 329, pl. 6, fig. 14.

This small species with 4-1/2 chambers per whorl is found only in pre-Quaternary samples from the Mediterranean drillsites.

\section{Hanzawaia boueana (d'Orbigny)}

(Plate 5, Figures 12-14)

V.t., Truncatulina boueana d'Orbigny, 1846, Foram. Foss. Bassin Tert. Vienne, p. 169, pl. 9, fig. 24-26.

Some of the Mediterranean specimens are similar to $T$. rhodiensis Terquem in having inflated chambers and in the absence of an umbilicus and a carinate periphery. Many other specimens reveal characteristics intermediate between these two species. Additional studies are necessary to determine if these two are part of a gradational lineage. For the present the older name is used but is used here to include traits of the younger species.

\section{Hoeglundina elegans (d'Orbigny)}

(Plate 5, Figures 15, 16)

Rotalia (Turbinulina) elegans d’Orbigny, 1826, Ann. Sci. Nat., Sér. 1, v. 7 , p. 276 , modèles no. 34 .

This species is found only in Quaternary strata at Site 378 where it is frequent.

\section{Hyalinea balthica (Schroeter)}

(Plate 5, Figure 17)

Nautilus balthicus Schroeter, 1783, Einleitung Conch. Linné, v. 1, p. 20 , pl. 1, fig. 2.

Many of the Mediterranean drillsite specimens of this species are very small; only one-third the size of the figured type and other illustrated specimens. These core specimens were probably living at or near their lower depth limit as described by Colom (1970). Only those specimens in the Quaternary strata of Site 378 are near normal in size.

\section{Karreriella bradyi (Cushman)}

(Plate 5, Figure 18)

Gaudryina bradyi Cushman, 1911, U. S. Nat. Mus. Bull., no. 71, p. 67, fig. 107.

For comments on this species see Eggerella bradyi.

Lagenonodosaria scalaris (Batsch)

Nautilus (Orthoceras) scalaris Batsch, 1791, Kupfer, Conch. Seesandes, Jena, Univ. Press, p. 1, 4, pl. 2, fig. 4.

This species is found sporadically at Site 372 .

\section{Loxostomum normale Galloway and Heminway}

(Plate 6, Figure 1)

Loxostonum normale Galloway and Heminway, 1941, N.Y. Acad. Sci., Sci. Surv. Puerto Rico and Virgin Is., v. 3, pt. 4, p. 421, pl. 31, fig. 4.

The Mediterranean drillsite specimens differ slightly from the figured type and do not have the well developed uniserial last chamber.

\section{Melonis affine (Reuss)}

(Plate 6, Figures 2, 3)

Nonionina affinis Reuss, 1851, Deutsch. Geol. Ges., Zeitschr., v. 3, p. 72 , pl. 5 , fig. 32 .
The taxonomy of the compressed Melonis with limbate sutures is unclear (Boltovskoy, 1958). M. barleeanum, M. formosum, M. padanum, and $M$. parkerae are all closely related to $M$. affine and the last three of these may be junior synonyms. The specimens in the drillsite samples have fewer than 10 chambers in the final whorl and a ratio of diameter to thickness of $2 / 2.3$. The sutures are radiate and are slightly curved and limbate. There is no strong umbilical rim of clear shell material and the umbilical pit, if present, is small and deep. The species is closely related to $M$. barleeanum and only detailed examination can separate the two.

\section{Melonis barleeanum (Williamson)}

(Plate 6, Figure 4)

V.t., Nonionina barleeana Williamson, 1858, Recent. Foram. Gt. Britain, Ray. Soc., p. 32, pl. 3, fig. 68,69.

This species differs from $M$. affine in having a rim of thickened shell material about a large umbilical depression, strongly limbate sutures and more than 10 chambers in the final whorl. It is frequent in many core samples.

\section{Melonis soldanii (d'Orbigny)}

(Plate 6, Figure 5)

Nonionina soldanii d'Orbigny, 1846, Foram. Foss. Bassin Tert. Vienne, p. 109, pl. 5, fig. 15, 16.

This species is often confused with $M$. pompilioides (Fichtel and Moll) but is differentiated by its smaller pores and more pronounced sutures which tend to be tangential to the umbilicus in contrast to the radiate and less well defined sutures of $M$. pompilioides.

\section{Miliolinella circularis (Bornemann)}

Triloculina circularis Bornemann, 1855, Deutsch. Geo. Ges., Zeitschr., v. 7 , no. 2, p. 349 , pl. 19 , fig. 4 .

This species is found infrequently in Quaternary samples in the eastern Mediterranean drillsites.

\section{Neoconorbina terquemi (Rzehak)}

Rosalina orbicularis Terquem (non d'Orbigny), 1876, Soc. Dunkerquoise, Mem., p. 75 , p. 166, pl. 9, fig. 4

Discorbina terquemi Rzehak, 1888, Geol. Reichsant., Verh., p. 228. This species occurs only in displaced samples.

\section{Nonion depressulus (Walker and Jacob)}

Nautilus depressulus Walker and Jacob, 1791, In, Kanmacher, F., Adams' Essays Micro., 2d ed., Dillon and Keating, London, p. 641 , pl. 14 , fig. 33

Nonion depressulus emend. Murray, 1965, Cushman Found. Foram. Res., Contrib., v. 16, pt. 4, p. 148, pl. 25, fig. 6, 7; pl. 26, fig. 7, 8.

The Mediterranean drillsite specimens usually have 7 chambers in the final whorl in contrast to the 9-10 chambers in Murray's emendation.

\section{Nonion scaphum (Fichtel and Moll)}

Nautilus scaphus Fichtel and Moll, 1798, Test. Micr., Wien, p. 105, pl. 19, fig. d-f.

The DSDP specimens have fewer and more inflated chambers than those illustrated by Fichtel and Moll. The specimens are also similar to Pseudononion japonicum Asano. This species usually occurs in displaced samples.

\section{Nonionella sp. A}

(Plate 6, Figures 6-8)

This is a compressed form whose chambers increase rapidly in size. There are usually 13 chambers with $7-9$ visible in the last whorl. The periphery is rounded. Initial sutures are flush and later ones depressed. The form is similar to that of $N$. auricula Heron-Allen and Earland.

\section{Nuttallides rugosus convexus (Parker)}

(Plate 6, Figures 9-12)

Epistominella rugosa convexa Parker, 1958, Swedish Deep-Sea Exped., Rpts., v. 8 , no. 4 , p. 273 , p. 4 , fig. $21-23$.

This species, a frequent component of many samples is placed here in Nuttallides because of the presence of an internal plate 
extending from the septal foramen to the peripheral part of the apertural opening (Plate 6, Figure 12).

\section{Nuttallides umboniferus (Cushman) \\ (Plate 6, Figures 13, 14)}

Pulvinulinella umbonifera Cushman, 1933, Cushman Lab. Foram. Res., Contrib., v. 9, pt. 4, p. 90, pl. 9, fig. 9.

Except for the aperture this species can be easily confused with Eponides bradyi Earland. Although originally described from the deep tropical Pacific this species is known here only in strata of early Pliocene age or older.

\section{Oridorsalis umbonatus (Reuss)}

(Plate 6, Figures 15-19)

Rotalina umbonata Reuss, 1851, Deutsch Geol. Ges., Zeitschr., v. 3, p. 75 , pl. 5 , fig. 35 .

Specimens of this species exhibit both a smooth and a lobate periphery. Included in the concept of $O$. umbonatus in the Leg $42 \mathrm{~A}$ samples are specimens with an acute periphery designated as Truncatulina tenera by Brady. Also included is the pre-Recent form with stellate sutures near the umbilicus referred to as $T$. tenera var. stellata by Silvestri. O. umbonatus is an abundant species in the cores.

\section{Orthomorphina exilis (Schwager)}

(Plate 7, Figure 1)

Nodosaria exilis Schwager, 1866, Novara Exped., Geol. Theil, v. 2, pt. 2, p. 223, pl. 5 , fig. 52.

The Mediterranean specimens have slightly shorter chambers than the figured types and are also similar to $O$. perversa (Brady).

\section{Orthomorphina pupoides (Silvestri)}

Nodosaria pupoides Silvestri, 1872, Accad. Gioenia Sci. Nat. Catania, Atti, ser. 3, v. 7, p. 65, pl. 6, fig. 148-158.

This species, like most of the orthomorphinids in the cores, occurs primarily in pre-Quaternary strata.

\section{Orthomorphina raphana (Parker and Jones)}

Uvigerina (Sagrina) raphanus Parker and Jones, 1865, Philos. Trans. Roy. Soc., v. 155, p. 364, pl. 18, fig. 16, 17.

\section{Osangularia cuher (Parker and Jones)}

(Plate 7, Figure 2, 3)

Planorbulina farcta (Fichtel and Moll) var. ungeriana (d'Orbigny) subvar. culter Parker and Jones, 1865, Philos. Trans. Roy. Soc. London, Philos. Trans., v. 155, p. 421 , pl. 19, fig. 1.

This strongly keeled form is found only in Miocene samples although it was originally described from deep Recent sediments of the tropical Atlantic.

\section{Planulina ariminensis d'Orbigny}

Planulina ariminensis d'Orbigny, 1826, Ann. Sci. Nat., ser. 1, v. 7, p. 280 , pl. 14, fig. 1-3.

Although scattered specimens of this species are found in several samples, only at Site 378 is it present in any quantity.

\section{Pleurostomella acuminata Cushman} (plate 7, Figure 4)

Pleurostomella acuminata Cushman, 1922 U. S. Nat. Mus. Bull., no. 104 , p. 50 , pl. 19, fig. 6 .

Although never frequent the pleurostomellids are persistent elements in many samples.

\section{Pleurostomella alternans Schwager \\ (Plate 7, Figure 5)}

Pleurostomella alternans Schwager, 1866, Novara Exped., Geol. Theil, v. 2 , no. 2 , p. 238 , pl. 6 , fig. 79,80 .

The chambers of the Mediterranean specimens are a bit less inflated than those of the figured types.

\section{Pleurostomella bierigi Palmer and Bermúdez}

Pleurostomella bierigi Palmer and Bermúdez, 1936, Soc. Cubana Hist. Nat., Mem., v. 10, p. 294, pl. 17, fig. 7, 8.

This species is closely related to and may be conspecific with $P$. brevis Schwager.

\section{Pseudoclavulina crustata Cushman}

(Plate 7, Figure 6)

Pseudoclavulina crustata Cushman, 1936, Cushman Lab. Foram.

Res., Spec. Publ. no. 6, p. 19, pl. 3, fig. 12.

This species is present only in the lower Pliocene of Site 378 and in the Serravallian of Site 372.

\section{Pullenia bulloides (d'Orbigny)}

(Plate 7, Figure 7)

V.t., Nonionina bulloides d'Orbigny, 1846, Foram. Foss. Bassin Tert. Vienne, p. 107, pl. 5, fig. 9, 10.

This species is described as having 4 chambers in the final whorl but some topotypes contain 5 chambers.

\section{Pullenia multilobata Chapman}

(Plate 7, Figures 8, 9)

Pullenia multilobata Chapman, 1900, Calif. Acad. Sci. Proc., Geol., ser. 3 , v. 1 , no. 8 , p. 253 , pl. 30 , fig. 7.

This species is restricted to middle Miocene-Pliocene strata.

\section{Pullenia osloensis Feyling-Hanssen}

(Plate 7, Figures 10, 11)

Pullenia quinqueloba (Reuss) subsp. minuta Feyling-Hanssen (non Cushman), 1954, Norsk Geol. Tidsskr., v. 33, no. 1-2, p. 133, pl. 2, fig. 3

Pullenia osloensis Feyling-Hanssen, 1954, Norsk Geol. Tidsskr., v. 33, no. 3-4, p. 194.

This species is easily confused with $P$. bulloides but consistently has 5 chambers in the final whorl, has slightly depressed sutures and is not as spherical as $P$. bulloides.

\section{Pullenia quinqueloba (Reuss) \\ (Plate 7, Figure 12)}

Nonionina quinqueloba Reuss, 1851, Deutsch. Geol. Ges., Zeitschr., v. 3 , p. 71 , pl. 5 , fig. 31 .

The type figure of Reuss is very similar to that of Nonionina subcarinata d'Orbigny but topotypes of the latter are much less compressed than the figure of Reuss indicates.

\section{Pullenia salisburyi Stewart and Stewart}

(Plate 7, Figure 13)

Pullenia salisburyi Stewart and Stewart, 1930,- J. Paleontol., v. 4, no. 1, p. 72 , pl. 8 , fig. 2 .

This species is more compressed than $P$. quinqueloba.

\section{Pullenia subcarinata (d'Orbigny)}

V.t., Nonionina subcarinata d'Orbigny, 1839, Amér. Mérid., v. 5, pt. 5 , p. 28 , pl. 5 , fig. 23,24 .

Examination of topotype material from the Malvinas (Falkland) Islands shows that d'Orbigny's figures, as often is the case, are not well drawn. The specimens have $5-1 / 2$ to 6 chambers per whorl, are less acute at the periphery than those figured, and are less compressed as well.

\section{Pyrgo depressa (d'Orbigny)}

V.t., Biloculina depressa d'Orbigny, 1826, Ann. Sci. Nat., sér. 1, v. 7, p. 298 , modèles no. 91 .

Both species of Pyrgo found in the Mediterranean drillsites are rare components in the samples and their presence may be the result of downslope transport.

\section{Pyrgo elongata (d'Orbigny)}

Biloculina elongata d’Orbigny, 1826, Ann. Sci. Nat., sér. 1, v. 7, p. 298.

Parker, Jones and Brady, 1871, Ann. Mag. Nat. Hist., ser. 4, v. 8, pl. 8, fig. 6 .

\section{Quinqueloculina lamarckiana d'Orbigny}

Quinqueloculina lamarckiana d'Orbigny, 1839, Cuba, p. 189, pl. 11, fig. 14,15 .

This species is present only in displaced samples. 


\section{Quinqueloculina venusta Karrer}

(Plate 7, Figure 15)

Quinqueloculina venusta Karrer, 1868, K. Akad. Wiss. Wien, Math. Naturw. Kl., v. 58 , no. 1 , p. 147 , pl. 2 , fig. 6 . The specimens in the cores are smaller than the figured types.

\section{Rectuvigerina royoi Bermúdez and Fuenmayor} (Plate 7, Figure 14)

Rectuvigerina royoi Bermúdez and Fuenmayor, 1963, Inst. Oceanogr., Univ. Oriente, Bol., v. 2, no. 2, p. 144, 145, pl. 18, fig. 9.

This species differs from Siphogenerina multicostata Cushman and Jarvis by being smaller and by having more delicate costae. It is also similar to and may have been identified as Uvigerina tenuistriata Reuss var. siphogenerinoides Lipparini or as Rectuvigerina phlegeri (LeCalvez). It is found only in the middle Miocene strata of Site 372 .

\section{Seabrookia earlandi Wright}

(Plate 7, Figure 16)

Seabrookia earlandi Wright, 1891, Roy. Irish Acad., Proc., ser. 3, v. 1 , no. 4 , p. 477 , pl. 2 , fig. 6,7 .

This species is found only at Sites 372 and 378

\section{Sigmoilina distorta Phleger and Parker}

Sigmoilina distorta Phleger and Parker, 1951, Geol. Soc. Am., Mem., v. 46 , pt. 2 , p. 8 , pl. 4 , fig. $3-5$.

This species is very rare in the core samples.

\section{Sigmoilina tenuis (Czjzek)}

(Plate 7, Figure 18)

V.t., Quinqueloculina tenuis Czjzek, 1848, Naturw. Abh., v. 2, no. 1, p. 149, pl. 13, fig. 31-34.

This species is a bit more common in the eastern Mediterranean sites than in those of the west.

\section{Sigmoilopsis schlumbergeri (Silvestri)}

(Plate 7, Figure 17)

V.t., Sigmoilina schlumbergeri Silvestri, 1904, Accad. Pont. Romana Nuovi Lincei, Mem., v. 22, p. 267, 269, pl. 7, fig. 12-14.

This species is a rare to frequent element in many samples from the Mediterranean drillsites.

\section{Siphonina reticulata (Czjzek)}

(Plate 7, Figure 19)

V.t., Rotalina reticulata Czjzek, 1848; Naturw. Abh., Wien, v. 2, no. 1, p. 145, pl. 13, fig. 7-9.

This species is frequent to common in many samples.

\section{Siphonina tubulosa Cushman}

(Plate 7, Figure 20),

Siphonina tubulosa Cushman, 1924, Carnegie Inst. Wash., Publ. no. 342 , p. 40 , pl. 13 , fig. 1,2 .

This species is rare in the drillsite samples.

\section{Sphaeroidina bulloides d'Orbigny}

(Plate 8, Figure 1)

Sphaeroidina bulloides d'Orbigny, 1826, Ann. Sci. Nat., sér. 1, v. 7, p. 267, modèles no. 65 .

This distinctive species is found in many samples but only in small numbers.

\section{Spiroloculina canaliculata d'Orbigny}

V.t., 1846, Foram. Foss. Bassin Tert. Vienne. p. 269, pl. 16, fig. 10-12. The spiroloculinids are rare in the core samples and may be present only in the displaced samples.

\section{Spiroloculina grata Terquem}

Spiroluculina grata Terquem, 1878, Soc. Géol. France, Mem., sér. 3, v. 1 , p. 55 , pl. 5, fig. 14,15 .

Stilostomella cf. $S$. annulifera (Cushman and Bermúdez) (Plate 8, Figure 2)

Ellipsonodosaria annulifera Cushman and Bermúdez, 1936, Cushman Lab. Foram. Res., Contrib., v. 12, pt. 2, p. 28, pl. 5, fig. 8, 9.
The drillsite specimens have somewhat larger chambers than the figured types. The stilostomellids are frequent here only in preQuaternary strata.

\section{Stilostomella antillea (Cushman)}

(Plate 8, Figures 3, 4)

Nodosaria antillea Cushman, 1923, U. S. Nat. Mus., Bull., no. 104, p. 91, pl. 14, fig. 9 .

The Mediterranean specimens have fewer chambers and less pronounced ornamentation than the figures of Cushman.

\section{Stilostomella lepidula (Schwager)}

(Plate 8, Figure 5)

Nodosaria lepidula Schwager, 1866, Novara Exped., Geol. Theil, v. 2, p. 20 , pl. 5 , fig. 27,88 .

\section{Trifarina angulosa angulosa (Williamson)}

(Plate 8, Figure 6)

Uvigerina angulosa Williamson, 1858, Rec. Foram. Gt. Britain, Ray. Soc., p. 67 , pl. 5 , fig. 140

This heavy walled form with a sharp triangular outline is not very abundant in the core samples.

\section{Trifarina angulosa pauperata (Heron-Allen and Earland)} (Plate 8, Figures 7, 8)

Uvigerina angulosa Williamson var. pauperata Heron-Allen and Earland, 1932, Discovery Repts., v. 4, p. 398, pl. 12, fig. 40-43.

This variable form differs from $T$. angulosa angulosa in having short spine-like projections at the base of the chambers and by being smaller and thinner walled. Some specimens exhibit chambers with an acute and overlapping lower margin. Some of the specimens are similar to forms described by Cushman as $U$. occidentalis.

\section{Trifarina bradyi Cushman}

(Plate 8, Figure 9),

Trifarina bradyi Cushman, 1923, U. S. Nat. Mus., Bull., no. 104, p. 99 , pl. 22, fig. 3-9.

The deep water Mediterranean specimens differ from the described types by being less tapered at the apertural end.

\section{Triloculina tricarinata d'Orbigny}

Triloculina tricarinita d'Orbigny, 1826, Ann. Sci. Nat., sér. 1, v. 7, p. 299, modèles no. 94 ,

Parker, Jones, and Brady, 1865, Ann. Magn. Nat. Hist., v. 16, Ser. 3, pl. 1, fig. 8 .

This species is found only in displaced samples.

\section{Uvigerina auberiana d'Orbigny}

(Plate 8, Figure 10)

Uvigerina auberiana d'Orbigny, 1839, Cuba, p. 106, pl. 2, fig. 23, 24.

The taxonomy of the hispid uvigerinids is very confused. In the Mediterranean cores there are a few large biserial forms that match those described by d'Orbigny.

\section{Uvigerina barbatula Macfayden}

Uvigerina barbatula Macfayden, 1930, Miocene Foram. Clysmic Area, Egypt. Geol. Surv., p. 92, pl. 3, fig. 26.

The figured types are free of costae on the last chamber but are otherwise identical to the specimens in the core samples. This species is found only in the Burdigalian of Site 372.

\section{Uvigerina hispida Schwager}

(Plate 8, Figure 11)

Uvigerina hispida Schwager, 1866, Novara Exped., Geol. Theil, v. 2 , no. 2 , p. 249 , pl. 7 , fig. 95 .

This species, characterized by large rounded hispid chambers, is confined to pre-Quaternary samples at Site 372 . It is the most common uvigerinid in the cores.

\section{Uvigerina laevis Goës}

Uvigerina auberiana Goës (non d'Orbigny), 1882, Sv. Vet. Ak. Hdl. v. 19 , no. 4 , p. 60 , pl. 4 , fig. $71-74$.

Uvigerina auberiana d'Orbigny var. laevis Goess, 1896, Harvard Coll., Mus. Comp. Zool., Bull., v. 29, p. 52. 
This species has less hispid and more elongate chambers than $U$. auberiana and is found in upper Miocene strata at Site 372.

\section{Uvigerina longistriata Perconig}

(Plate 8, Figure 12)

Uvigerina longistriata Perconig, 1955, Italy Serv. Geol., Boll., v. 77, no. $2-3$, p: 182 , pl. 2, fig. 1-4.

The Mediterranean core specimens differ from the figured types only in having fewer costae per chamber. This species is distinguished from $U$. rutila by its numerous weak costae and by the absence of a spinose projection at the chamber base. It is confined to middle Miocene-Pliocene strata in the cores.

\section{Uvigerina mediterranea Hofker}

(Plate 8, Figure 13)

V.t., 1932, Staz. Zool. Napoli, Pubbl., v. 12, no. 1, p. 118, 119, fig. 32.

This is a common species in the Mediterranean today but is not of ten recorded in the Neogene samples.

\section{Uvigerina mioindex (Finlay)}

(Plate 8, Figure 14)

Hopkinsina mioindex Finlay, 1947, New Zeal. J. Sci. Technol., sec. B, v. 28 , no. 5 , p. 282 , pl. 5 , fig. $80-82$.

This elongate species with its relatively coarse costae is part of the $U$. tenuistriata Reuss lineage including $U$. bononiensis Fornasini and $U$. schencki Asano. It is thinner and more elongate than the first of these and has finer costae than the latter. It occurs in upper Miocene and lower Pliocene drillsite samples.

\section{Uvigerina peregrina Cushman}

Uvigerina peregrina Cushman, 1922, U.S. Nat. Mus., Bull., no. 104, p. 166, pl. 42, fig. 7-10.

The Mediterranean specimens have high blade-like costae in contrast to the low blunt costae of $U$. mediterrenea.

\section{Uvigerina peregrina dirupta Todd, 1948}

(Plate 8, Figure 15)

Uvigerina peregrina dirupta Todd, 1948 Cushman and McCulloch, Univ. South. Calif. Publ., Allan Hancock Pacific Exped., v. 6, no. 5 , p. 267 , pl. 34 , fig. 3 .

The costae break up into spines near the apertural end of this species which is widespread but not frequent in the drillsite samples.

\section{Uvigerina proboscidea Schwager}

(Plate 8, Figure 16)

Uvigerina proboscidea Schwager, 1866, Novara Exped., Geol. Theil, v. 2 , no. 2 , p. 250 , pl. 7 , fig. 96 .

This species may of ten have been identified as $U$. auberiana but it is not biserial. It differs from $U$. hispida in having more fine short spine bases. It is also more fusiform and acuminate than the stout, globular chambered $U$. hispida. It occurs in Langhian to Messinian strata of Site 372.

\section{Uvigerina rutila Cushman and Todd}

(Plate 8, Figure 17)

V.t., 1941, Cushman Lab. Foram. Res., Contrib., v. 17, p. 78, pl. 20, fig. 16-22.

Although similar to $U$. longistriata, this species is distinguished by 8-10 strong costae per chamber, each of which ends in a short basal projection; the chambers overlap. $U$. rutila may be a junior synonym of $U$. multicostata Le Roy which has about 15 costae per chamber. This species occurs in Serravallian to lower Pliocene strata here.

\section{Valvulineria complanata (d'Orbigny)}

(Plate 8, Figure 18, 19)

V.t., Rosalina complanata d'Orbigny, 1846, Foram Foss. Bassin Tert. Vienne, p. 175, pl. 10, fig. 13-15.

The Mediterranean drillsite specimens differ from the topotypes in the absence of well-developed pustules of clear shell material on the umbilical margin of each chamber. These specimens are also very similar to topotypes of Rosalina araucana d'Orbigny from Valparaiso, Chile but lack the slightly carinate spiral side of that species. $V$. complanata has often been described as Discorbina bradyana Fornasini in the Mediterranean area. Examination of topotype material of that species shows it to fall within the range of variation of $V$. complanata. $V$. mira Conato is probably a junior synonym of $V$. complanata. This species is widespread in the core samples.

\section{Vulvulina pennatula (Batsch)}

Nautilus (Orthoceras) pennatula Batsch, 1791, Kupfer. Conch. Seesands, Jena Univ. Press. v. 3, 5, pl. 4, fig. 13.

This agglitinate species occurs only in pre-Quaternary samples of the Mediterranean cores.

\section{REFERENCES}

Boltovskoy, E., 1958. Problems in taxonomy exemplified by Nonion affine (Reuss): Micropaleontology, v. 4, no. 2, p. 193-200.

1959, Foraminiferos recientes del sur de Brasil y sus relaciones con los de Argentina: Serv. Hidro. Naval H. 1005 , p. $1-120$.

Colom, G., 1970. Estudio de los foraminiferos de muestras de fondo de la costa de Barcelona: Inv. Pesq., v. 34, no. 2, p. 355-384.

Forsanini, C., 1901. Contributo ala conoscenza delle Bulimine adriatiche: Mem. R. Accad. Sci. Inst. Bologna, ser. 5, v. 4 , p. $371-372$.

Heron-Allen, E. and Earland, A., 1932. Foraminifera, Part 1, The ice-free area of the Falkland Islands and adjacent seas: Discovery Rept., v. 4, p. 291-460.

Lankford, R. and Phleger, F. B., 1973. Foraminifera from the near-shore turbulent zone, western North America: J. Foram. Res., v. 3, pt. 3, p. 101-132.

Marks, P., 1951. A revision of the smaller foraminifera of the Vienna Basin: Cushman Found. Foram. Res., Contrib., v. 2, pt. 2, p. 33-73.

Parker, F. L., 1954. Distribution of the foraminifera in the northeastern Gulf of Mexico: Harvard Col., Mus. Comp. Zool., Bull., v. 111 , no. 10, p. 453-588.

Phleger, F. B., Parker, F. L., and Peirson, J. F., 1953. North Atlantic foraminifera: Swedish Deep-Sea Exp. Rept., v. 7, p. 1-122.

Ramanathan, Rm., 1975. Ecology and distribution of foraminifera in Vellar Estuary and adjoining environs off Portonovo, India: unpubl. Ph.D. thesis, Annamalai Univ., Annamalainagar, India.

Schnitker, D., 1974. Ecotypic variation in Ammonia beccarii (Linné): J. Foram. Res., v. 4, pt. 4, p. 216-223. 


\section{PLATE 1}
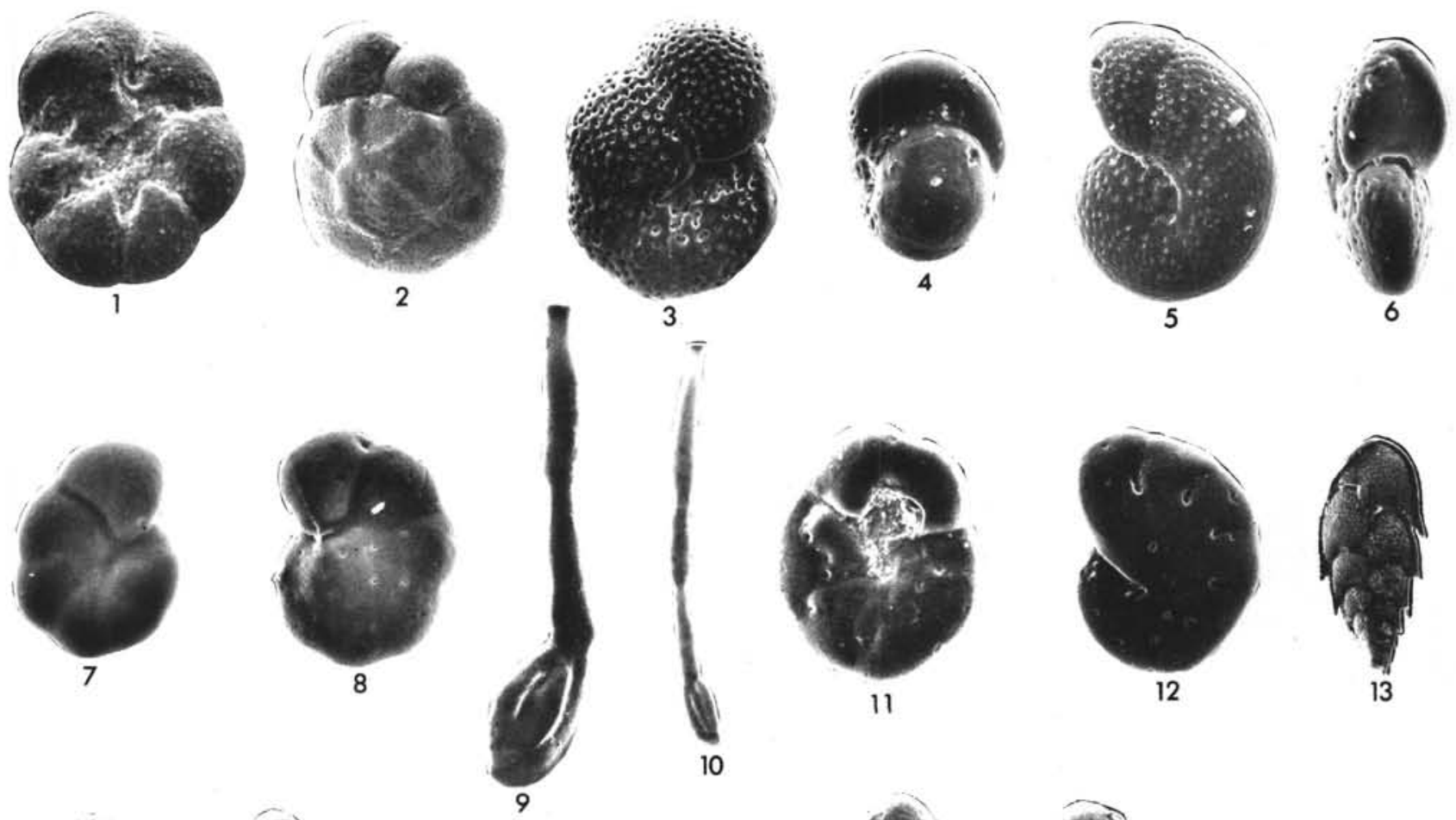
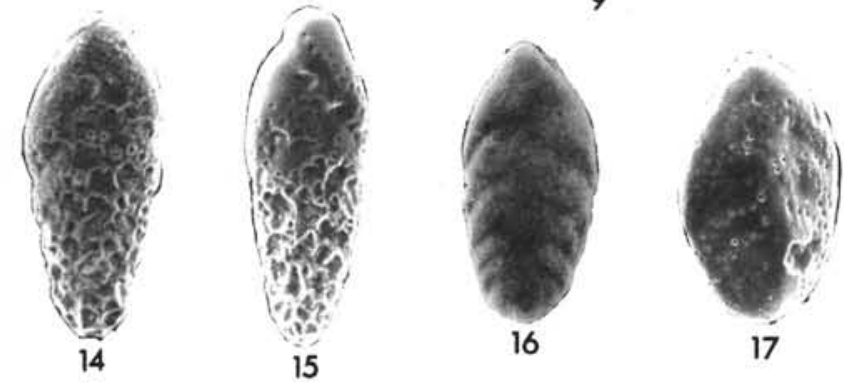

Figures 1, 2 Ammonia beccarii.

1. Sample 372-9-2, $0 \mathrm{~cm}, 238 \mu \mathrm{m}$.

2. Sample 376-9-3, $135 \mathrm{~cm}, 236 \mu \mathrm{m}$.

Figures 3, 4 Anomalinoides badensis.

3. Sample $372-11-1,140 \mathrm{~cm}, 836$ $\mu \mathrm{m}$.

4. Sample $372-9-4,120 \mathrm{~cm}, 234 \mu \mathrm{m}$.

Figures 5, 6 A. Flinti, Sample 372-9-3, $40 \mathrm{~cm}$.
5. $387 \mu \mathrm{m}$.
6. $174 \mu \mathrm{m}$.

Figures 7, 8 A. pseudogrosserugosa, Sample 371$2-1,145 \mathrm{~cm}$.

7. $137 \mu \mathrm{m}$.

8. $147 \mu \mathrm{m}$.

Figures 9, 10 Articulina tubulosa Sample 371-1-3, $120 \mathrm{~cm}$.

9. $1031 \mu \mathrm{m}$.

10. $861 \mu \mathrm{m}$.

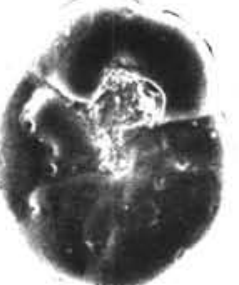

11
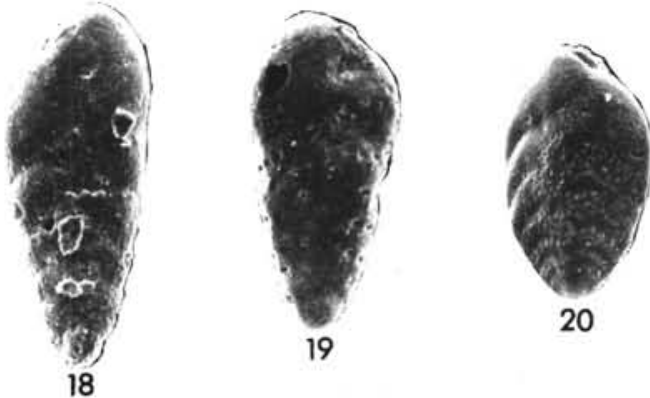

Figure 11

Figure 12

Figure 13

Figures 14, 15

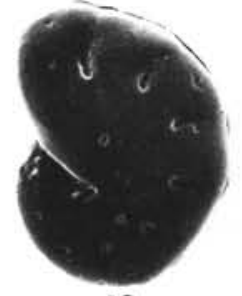

12

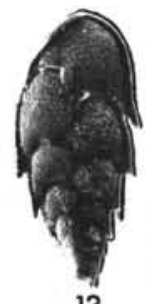

13

Asterigerinata mamilla, Sample 374372-3, CC, $215 \mu \mathrm{m}$.

Bolivina alata, Sample 378-3, CC, B. albatrossi.
15. Sample 378-1, CC, $271 \mu \mathrm{m}$.

14. Sample 372-4-1, $60 \mathrm{~cm}, 232 \mu \mathrm{m}$. 


\section{PLATE 2}
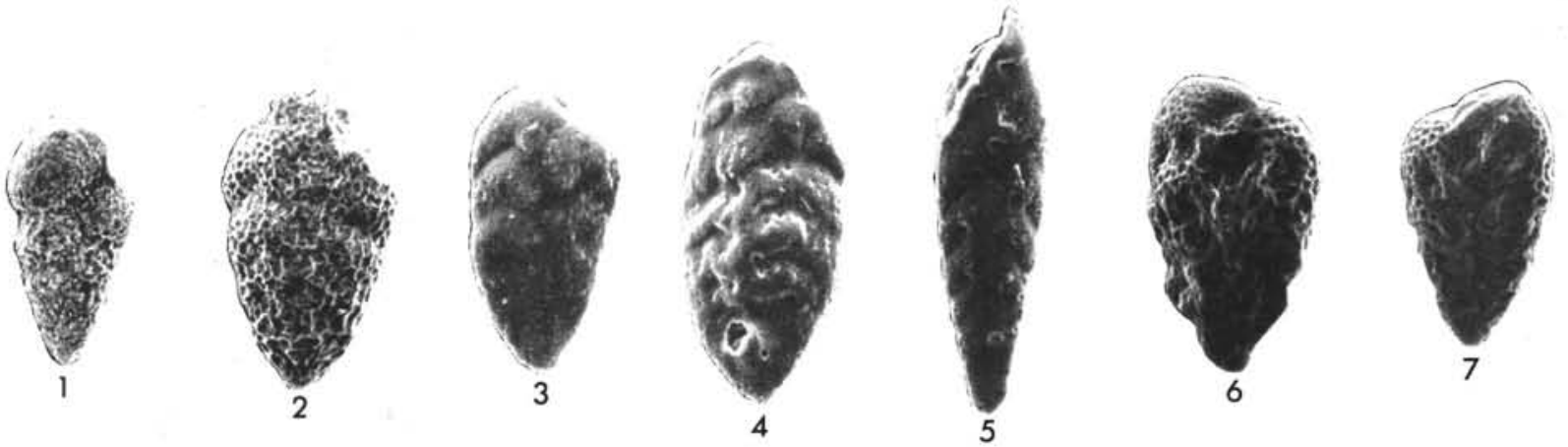
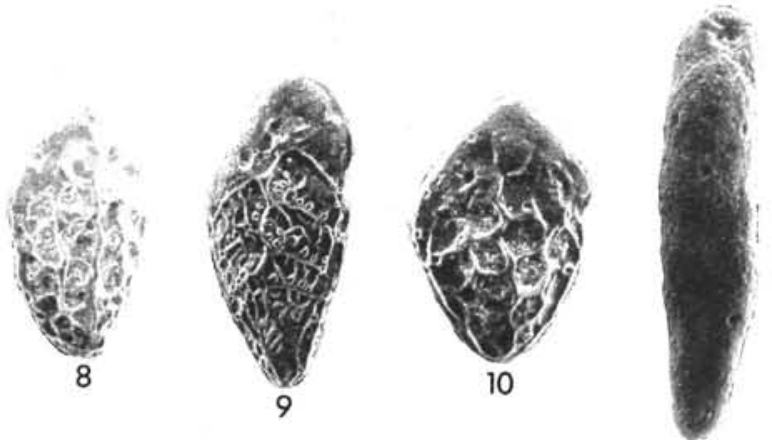

11

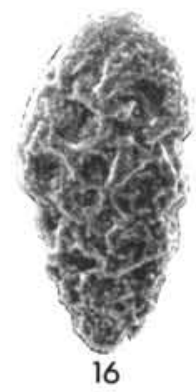

Figure 1

Figure 2

Figures 3, 4

Figure 5

Figures 6, 7

Figures 8-10

Figure 11
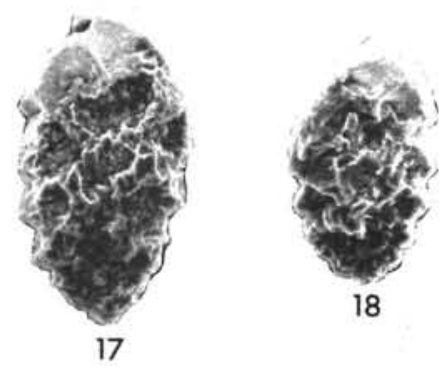

Bolivina globulosa, Sample 372-3, CC, $172 \mu \mathrm{m}$.

$B$. hebes, Sample 372-9-3, $140 \mathrm{~cm}$, $246 \mu \mathrm{m}$.

B. parvula, Sample $372-4-1,128 \mathrm{~cm}$. 3. $145 \mu \mathrm{m}$.

4. $170 \mathrm{~m}$.

B. placentina, Sample $374-4-2,60$ $\mathrm{cm}, 271 \mu \mathrm{m}$.

B. pseudoplicata, Sample 372-9-2, $100 \mathrm{~cm}$.

6. $271 \mu \mathrm{m}$.

7. $236 \mu \mathrm{m}$.

B. reticulata.

8. Sample 372-4, CC, $352 \mu \mathrm{m}$.

9. Sample $372-9-1,120 \mathrm{~cm}, 310 \mu \mathrm{m}$.

10. Sample 372-9-2, $100 \mathrm{~cm}$. $161 \mu \mathrm{m}$.

B. silvestrina, Sample 372-13-5, 120 $\mathrm{cm}, 401 \mu \mathrm{m}$.
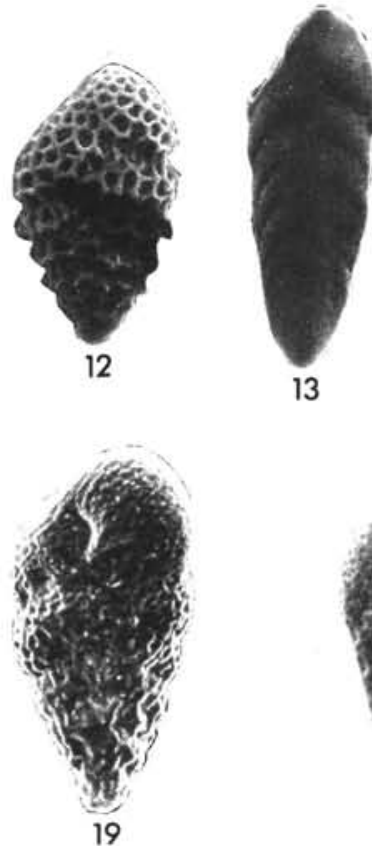
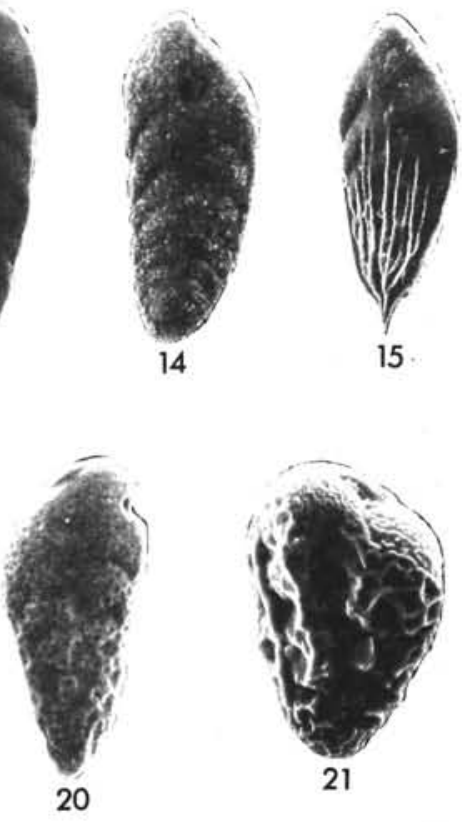

Figure 12

Figures 13, 14

B. cf. simpsoni, Sample 372-10,2 $130 \mathrm{~cm}, 139 \mu \mathrm{m}$.

B. spathulata.

13. Sample $372-12-6,120 \mathrm{~cm}, 368 \mu \mathrm{m}$.

14. Sample 372-10-1, $130 \mathrm{~cm}, 232 \mu \mathrm{m}$.

Figure 15

Figure 16

B. subaenariensis, Sample 372-12-6, $120 \mathrm{~cm}, 348 \mu \mathrm{m}$.

B. sublobata, Sample 372-10-2, 130 $\mathrm{cm}, 182 \mu \mathrm{m}$.

Figures 17,18

B. cf. thalmani.

17. Sample 372-9-4, $120 \mathrm{~cm}, 172 \mu \mathrm{m}$.

18. Sample 372-13-2, $20 \mathrm{~cm}, 132 \mu \mathrm{m}$.

Figures 19, 20

$B$. variablis.

19. Sample $372-9-1,120 \mathrm{~cm}, 176$ $\mu \mathrm{m}$.

20. Sample $372-12-6,120 \mathrm{~cm}, 252$ $\mu \mathrm{m}$.

Figure 21 $372-4-2,90 \mathrm{~cm}, 124 \mu \mathrm{m}$. 

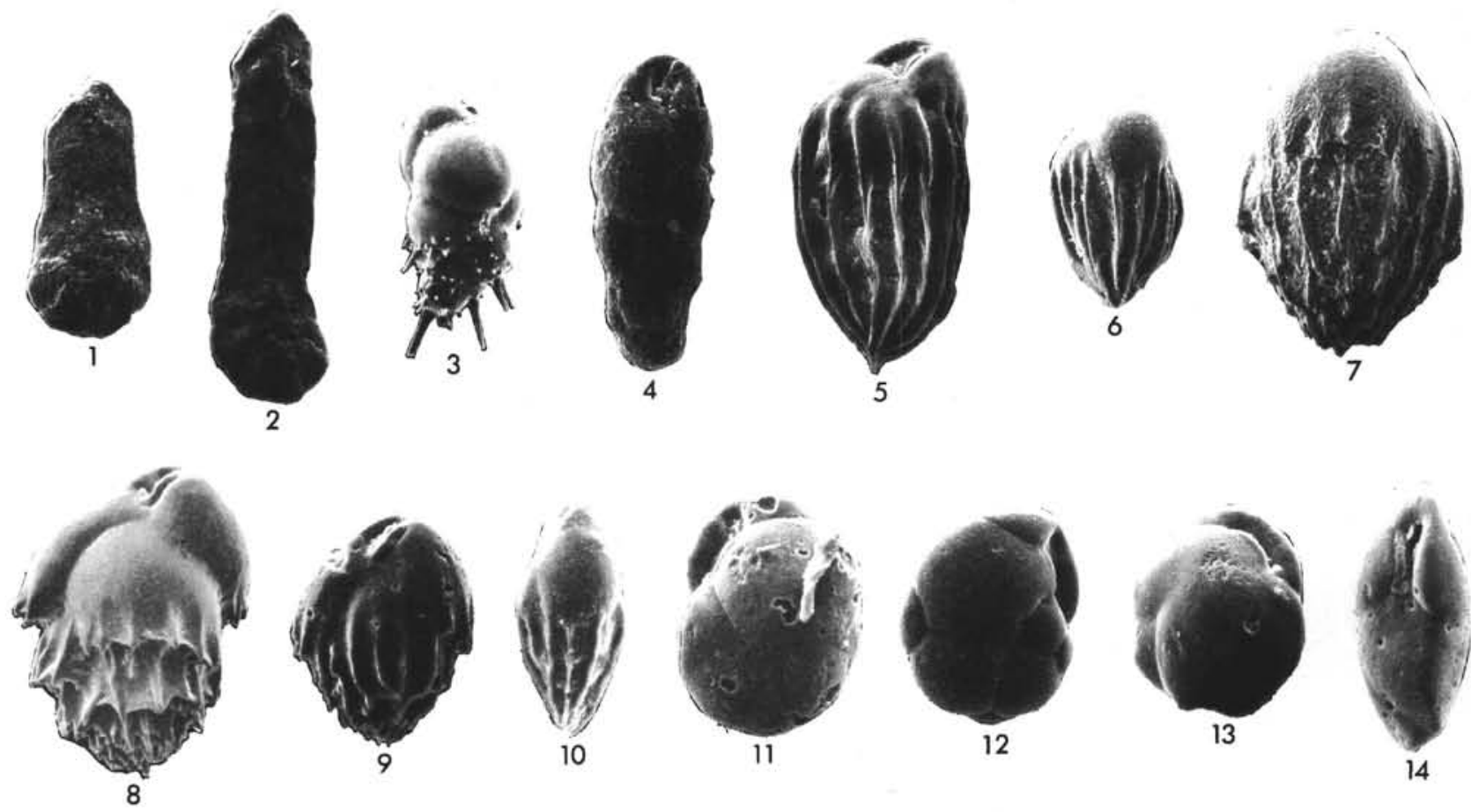

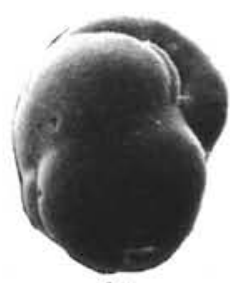

15

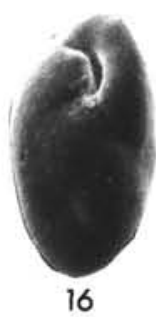

Bolivinopsis compta, Sample 372-10-1, $130 \mathrm{~cm}$.

1. $480 \mu \mathrm{m}$.

2. $333 \mu \mathrm{m}$.

Figure 3

Bulimina aculeata, Sample 373A-1-5, $134 \mathrm{~cm}, 310 \mu \mathrm{m}$.

Figure 4

B. affecta, Sample $372-4-2,90 \mathrm{~cm}$,

Figures 5, 6 $238 \mu \mathrm{m}$.

B. alazanensis.

5. Sample 372-9-2, $0 \mathrm{~cm}, 524 \mu \mathrm{m}$.

Figure 7

6. Sample 372-4-2, $90 \mathrm{~cm}, 219 \mu \mathrm{m}$.

Figures 8, 9

B. buchiana, Sample 372-11, CC, 401 $\mu \mathrm{m}$.

B. inflata.

8. Sample 372-1, CC, $230 \mu \mathrm{m}$.

9. Sample 372-13-2, $20 \mathrm{~cm}, 103 \mu \mathrm{m}$.

Figure 10

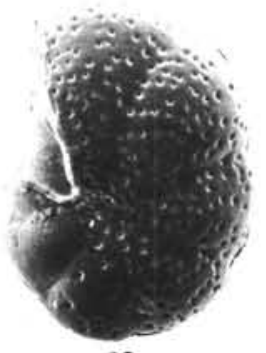

18

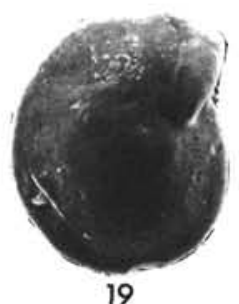

19

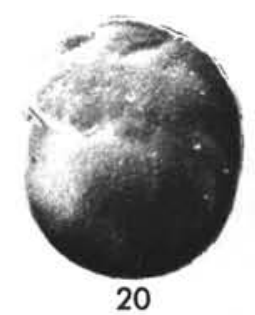

Figures 11, 12 Cassidulina crassa.

11. Sample $372-3-3,62 \mathrm{~cm}, 302 \mu \mathrm{m}$.

12. Sample $372-13-6,120 \mathrm{~cm}, 122 \mu \mathrm{m}$.

Figures 13, 14 C. laevigata.

13. Sample $372-4-2,60 \mathrm{~cm}, 141 \mu \mathrm{m}$.

14. Sample $372-13-6,120 \mathrm{~cm}, 192 \mu \mathrm{m}$.

Figures 15, 16 C. minuta, Sample 372-13-6, $120 \mathrm{~cm}$.

15. $134 \mu \mathrm{m}$.

16. $128 \mu \mathrm{m}$.

Figure 17

C. subglobosa, Sample 372-13-6, 120

Figure 18 $\mathrm{cm}, 112 \mu \mathrm{m}$.

Cibicides aknerianus, Sample $372-16-6,120 \mathrm{~cm}, 410 \mu \mathrm{m}$.

Figures 19, 20 C. pachydermus.

19. Sample $372-4-2,90 \mathrm{~cm}, 329$ $\mu \mathrm{m}$.

20. Sample $372-13-6,120 \mathrm{~cm}, 495$ $\mu \mathrm{m}$. 

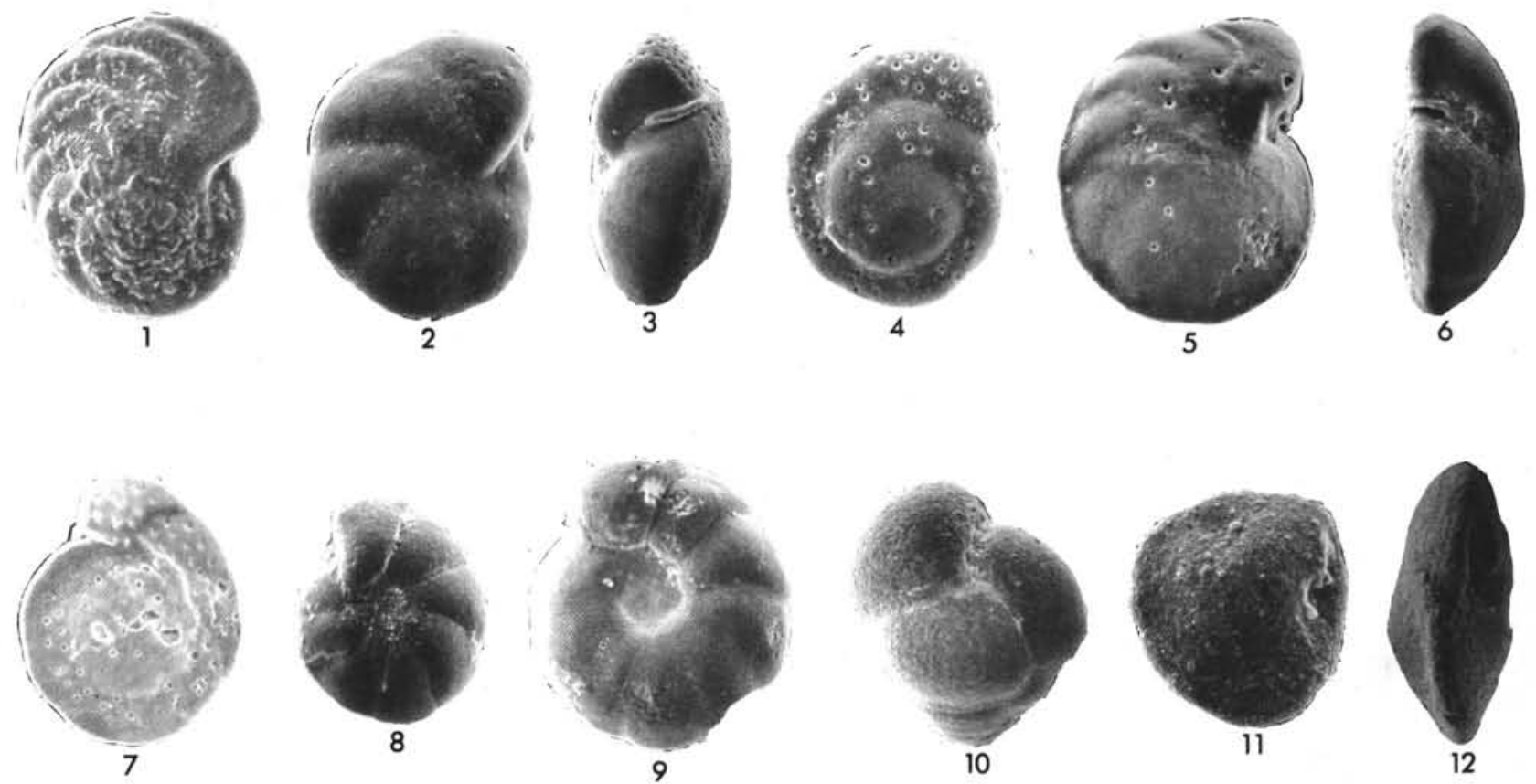
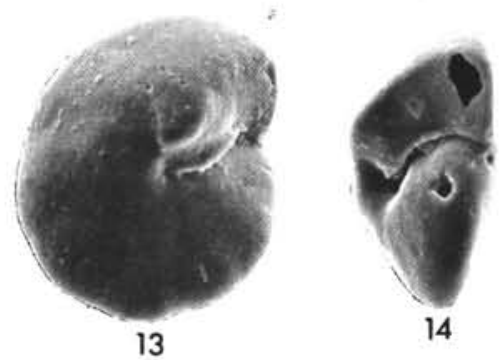

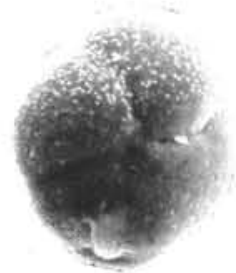

15

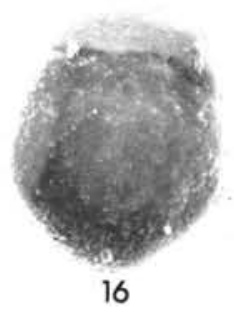

Cibicides wuellerstorfi, Sample $372-13-5,120 \mathrm{~cm}, 254 \mu \mathrm{m}$.

Figures 3, 4 C. bradyi, Sample 372-14, CC.
3. $373 \mu \mathrm{m}$.

4. $259 \mu \mathrm{m}$.

Figure 2 Cibicidoides bradyi, Sample 372-14, CC, $217 \mu \mathrm{m}$.

Figures 5-7 C. kullenbergi, Sample 372-3-2, $40 \mathrm{~cm}$.

5. $348 \mu \mathrm{m}$.

6. $271 \mu \mathrm{m}$.

7. Sample $372-3-4,40 \mathrm{~cm}, 238 \mu \mathrm{m}$.

Figure 8

C. aff. kullenbergi, Sample 372-14, CC, $308 \mu \mathrm{m}$.

Figure 9

C. robertsonianus, Sample 372-3-2, 40 $\mathrm{cm}, 501 \mu \mathrm{m}$.
Figure 10

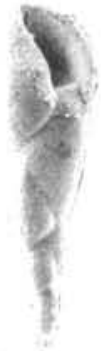

17

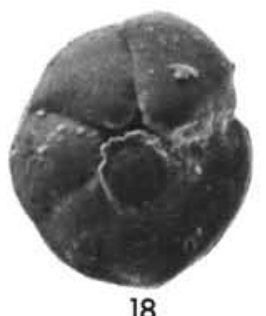

Eggerella bradyi, Sample 372-13-2, 20 $\mathrm{cm}, 480 \mu \mathrm{m}$.

Figure 11, 12 Epistominella exigua.

11. Sample 372-10-1, $130 \mathrm{~cm}, 182 \mu \mathrm{m}$. 12. Sample 372-12-3, $80 \mathrm{~cm}, 190 \mu \mathrm{m}$.

Figure 13, 14 Eponides polius, Sample 372-10-1, 130 $\mathrm{cm}$.

13. $159 \mu \mathrm{m}$.

14. $141 \mu \mathrm{m}$.

Figure 15, 16 E. pusillus, Sample 372-10-2. $130 \mathrm{~cm}$. 15. $112 \mu \mathrm{m}$.

16. $134 \mu \mathrm{m}$.

Figure 17 Fursenkoina complanata, Sample 371-4-3, $110 \mathrm{~cm}, 406 \mu \mathrm{m}$.

Figure 18
Gavelinopsis praegeri, Sample 378-11-4, $110 \mathrm{~cm}, 219 \mu \mathrm{m}$. 


\section{PLATE 5}
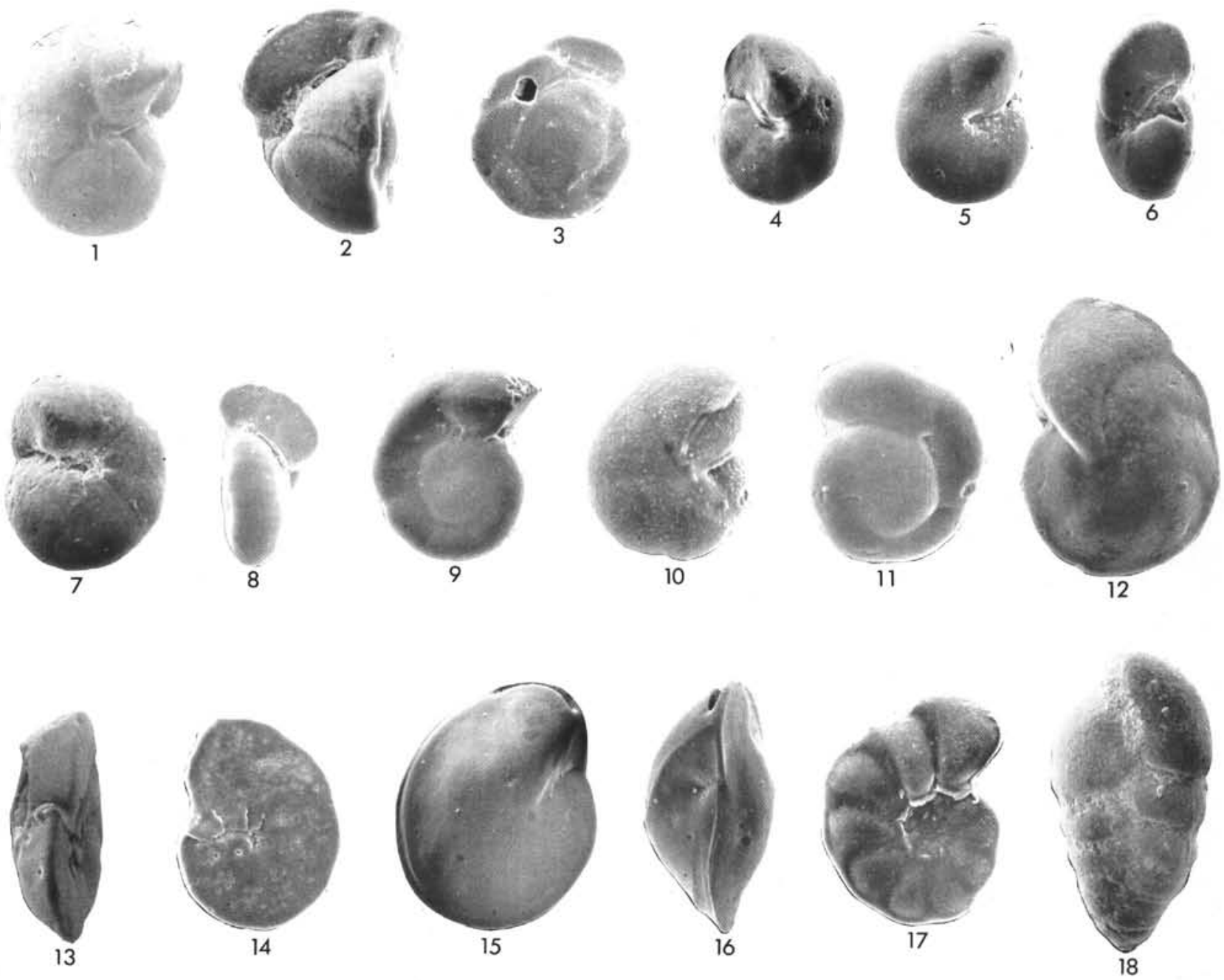

Figures 1-3 Gyroidina altiformis.

1. Sample 372-13-5, $120 \mathrm{~cm}, 368 \mu \mathrm{m}$.

2. Sample 372-21-3, $140 \mathrm{~cm}, 395 \mu \mathrm{m}$.

3. Sample $372-13-4,80 \mathrm{~cm}, 323 \mu \mathrm{m}$.

Figure 4

G. delicata, Sample $372-10-2,130 \mathrm{~cm}$, $145 \mu \mathrm{m}$.

Figures 5, $6 \quad$ G. orbicularis, Sample 372-10-1, 130 $\mathrm{cm}$.

5. $265 \mu \mathrm{m}$.

6. $174 \mu \mathrm{m}$.

Figures 10,11 G. umbonata, Sample 372-10-1, 130 $\mathrm{cm}$.

10. $143 \mu \mathrm{m}$.

11. $137 \mu \mathrm{m}$.

Figures 12-14 Hanzawaia boueana.

12. Sample 372-4, CC, $257 \mu \mathrm{m}$.

13. Sample 372-9-2, $100 \mathrm{~cm}, 195 \mu \mathrm{m}$.

14. Sample 372-9-2, $100 \mathrm{~cm}, 205 \mu \mathrm{m}$.

Figures 15, 16 Hoeglundina elegans, Sample 378-2, CC.

15. $670 \mu \mathrm{m}$.

16. $348 \mu \mathrm{m}$.

Figures 7-9 G. soldanii, Sample 372-3-2, $40 \mathrm{~cm}$.

Figure 17

7. $470 \mu \mathrm{m}$.

8. $588 \mu \mathrm{m}$.

Haylinea balthica, Sample 378-1-2, 80

9. $296 \mu \mathrm{m}$.

Figure 18 $\mathrm{cm}, 348 \mu \mathrm{m}$.

Karreriella bradyi, Sample 372-16-6, $120 \mathrm{~cm}, 958 \mu \mathrm{m}$. 


\section{PLATE 6}
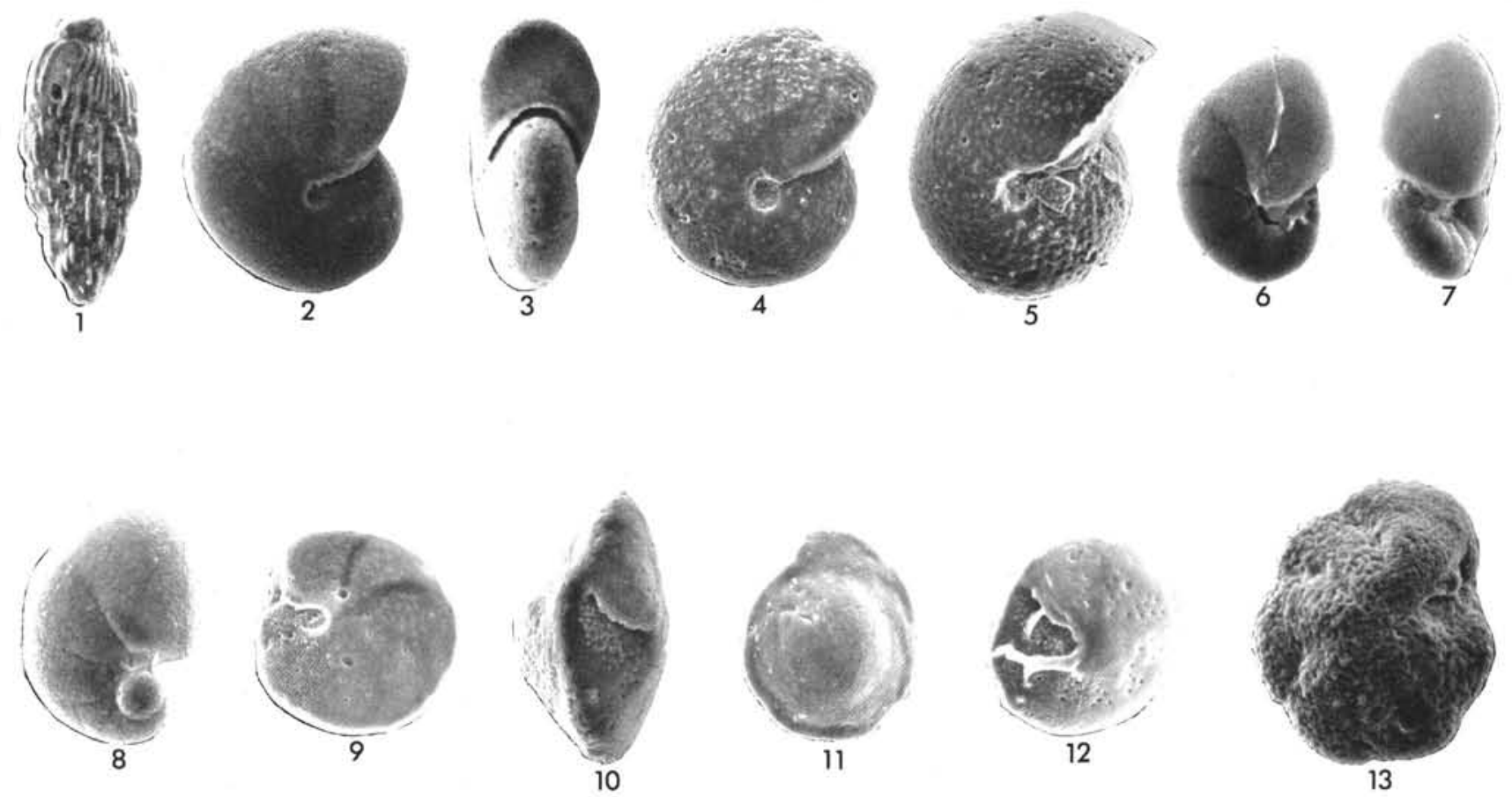

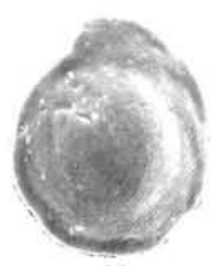

11

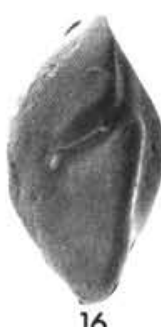

16
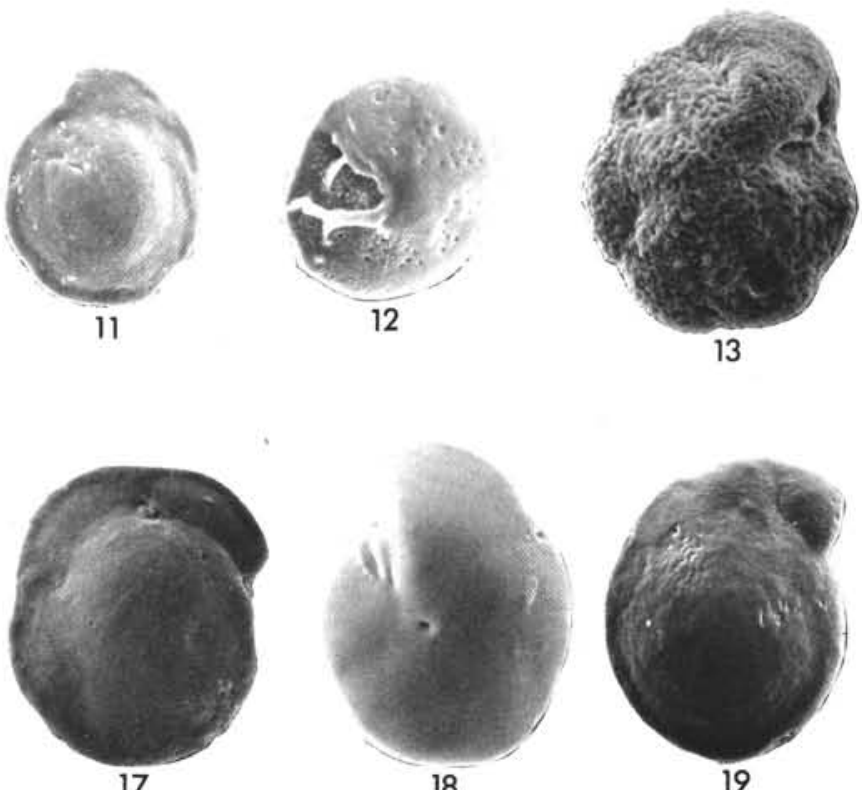

13
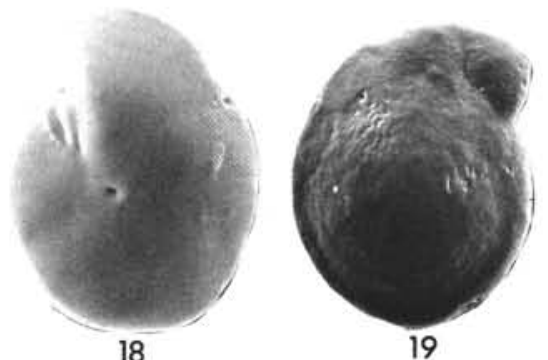

Figure 1

Loxostomum normale, Sample 372-4-1, $128 \mathrm{~cm}, 234 \mu \mathrm{m}$.

Figures 2, 3 Melonis affine.

2. Sample 372-4-1, $60 \mathrm{~cm}, 213 \mu \mathrm{m}$.

3. Sample $372-4-1,60 \mathrm{~cm}, 182 \mu \mathrm{m}$.

Figure 4 M. barleeanum, Sample 372-13-4, 80 $\mathrm{cm}, 375 \mu \mathrm{m}$.

Figure $5 \quad M$. soldanii, Sample $372-13-4,80 \mathrm{~cm}$,

Figures 6-8 $410 \mu \mathrm{m}$.

Nonionella sp. A, Sample 371-4-3, 110 $\mathrm{cm}$.

6. $116 \mu \mathrm{m}$.

7. $130 \mu \mathrm{m}$.

8. $116 \mu \mathrm{m}$.
Figures 9-12

Nuttaliides rugosus convexus.

9. Sample 372-13-6, $120 \mathrm{~cm}, 116 \mu \mathrm{m}$.

10. Sample $372-13-6,120 \mathrm{~cm}, 97 \mu \mathrm{m}$.

11. Sample $372-13-3,80 \mathrm{~cm}, 114 \mu \mathrm{m}$.

12. Sample $372-13-6,120 \mathrm{~cm}, 97 \mu \mathrm{m}$.

Figures 13, 14 N. umboniferus.

13. Sample $372-13-1,110 \mathrm{~cm}, 157 \mu \mathrm{m}$. 14. Sample $372-13-6,120 \mathrm{~cm}, 122 \mu \mathrm{m}$.

Figures 15-19

15. Sample 372-13-1, $110 \mathrm{~cm}, 294 \mu \mathrm{m}$.

16. Sample 372-3-2, $40 \mathrm{~cm}, 397 \mu \mathrm{m}$.

17. Sample 372-3-2, $40 \mathrm{~cm}, 294 \mu \mathrm{m}$.

18. Sample $376-5-5,50 \mathrm{~cm}, 124 \mu \mathrm{m}$.

19. Sample 372-3-3, $62 \mathrm{~cm}, 188 \mu \mathrm{m}$. 


\section{PLATE 7}

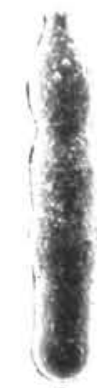

1

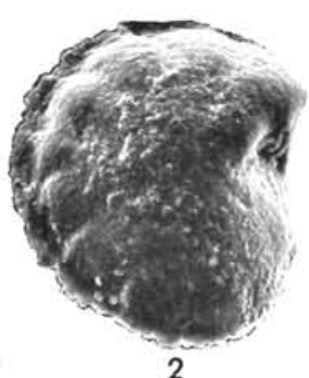

2
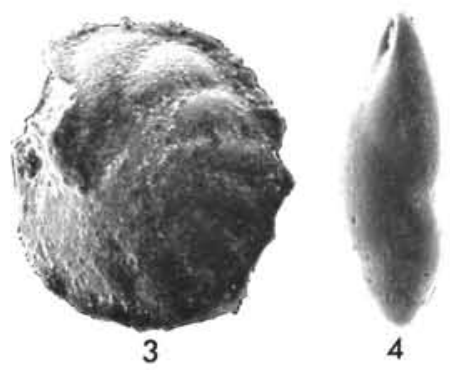
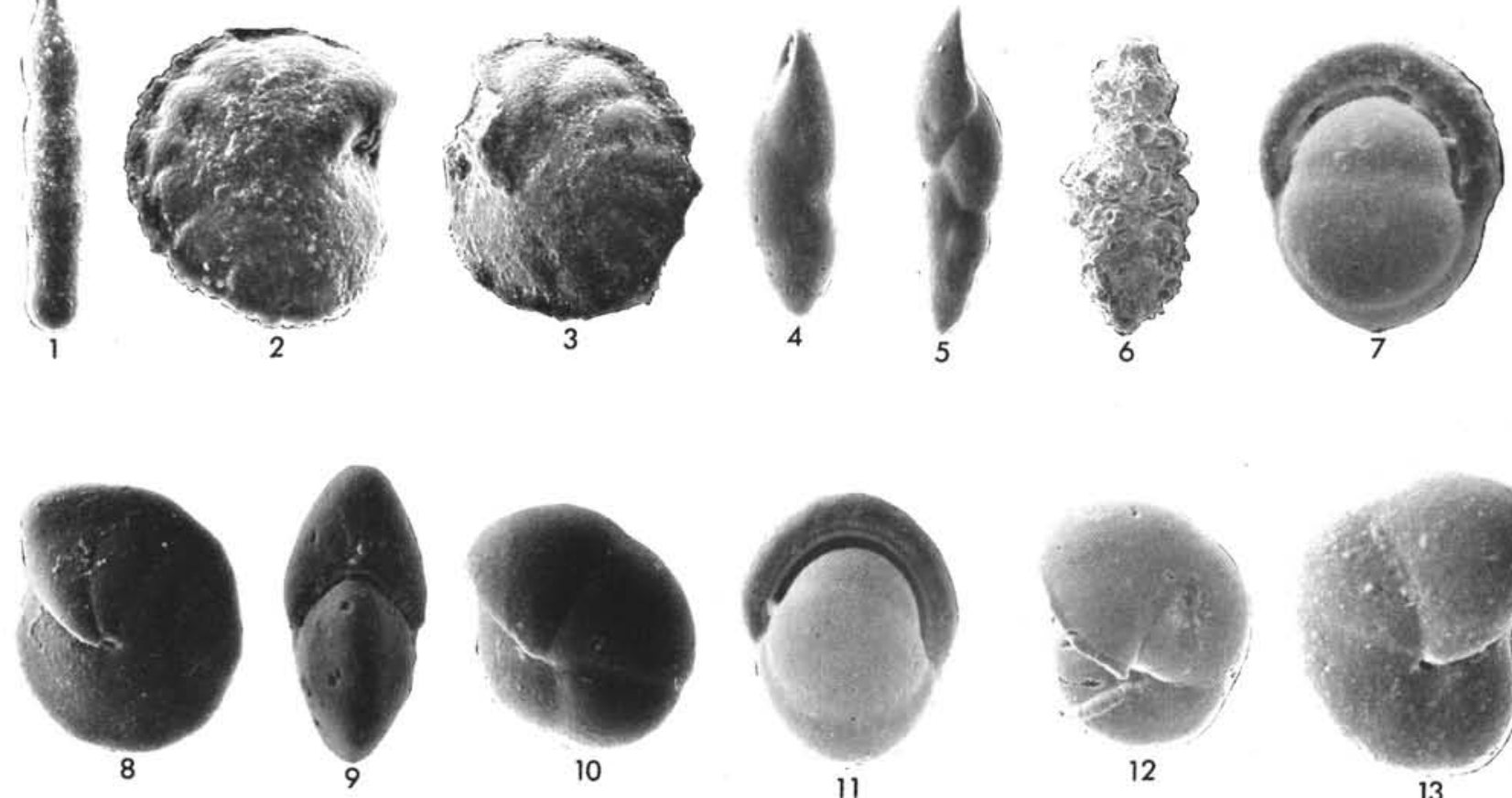

11

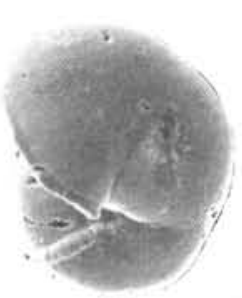

12

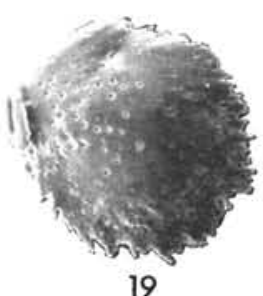

16

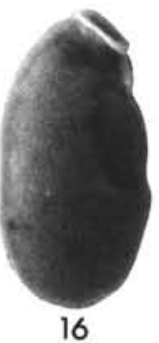

14

Figure 1

Figures 2, 3

Orthomorphina exilis, Sample $372-13-2,80 \mathrm{~cm}, 341 \mu \mathrm{m}$.

Osangularia culter.

2. Sample 372-13-2, $20 \mathrm{~cm}, 271 \mu \mathrm{m}$.

3. Sample 372-13-1, $110 \mathrm{~cm}, 406 \mu \mathrm{m}$.

Figure 4

Figure 5 Pleurostomella acuminata, Sample $372-12-5,120 \mathrm{~cm}, 372 \mu \mathrm{m}$.

$P$. alternans, Sample $372-3-3,62 \mathrm{~cm}$, $542 \mu \mathrm{m}$.

Figure 6

Figure 7

Pseudoclavulina crustata, Sample $378-1-2,80 \mathrm{~cm}, 809 \mu \mathrm{m}$.

Pullenia bulloides, Sample 372-13-2, $20 \mathrm{~cm}, 331 \mu \mathrm{m}$.

Figures 8, 9 P. multilobata.

8. Sample 372-12-6, $120 \mathrm{~cm}, 352, \mu \mathrm{m}$.

9. Sample $372-12-4,30 \mathrm{~cm}, 252 \mu \mathrm{m}$.

Figures 10,11 P. osloensis, Sample $372-12-4,80 \mathrm{~cm}$. 10. $271 \mu \mathrm{m}$.

11. $234 \mu \mathrm{m}$.
Figure 12

Figure 13

Figure 14

Figure 15

Figure 16

Figure 17

Figure 18

Figure 19

Figure 20
P.quinqueloba, Sample 372-12-6, 120 $\mathrm{cm}, 300 \mu \mathrm{m}$.

$P$. salisburyi, Sample $372-12-6,120$ $\mathrm{cm}, 178 \mu \mathrm{m}$.

Rectuvigerina royoi, Sample 372-13-2, $20 \mathrm{~cm}, 896 \mu \mathrm{m}$.

Quinqueloculina venusta, Sample $378-1-2,80 \mathrm{~cm}, 366 \mu \mathrm{m}$.

Seabrookia earlandi, Sample 378-1-2, $80 \mathrm{~cm}, 120 \mu \mathrm{m}$.

Sigmoilopsis schlumbergeri, Sample $378-1-2,80 \mathrm{~cm}, 395 \mu \mathrm{m}$.

Sigmoilina tenuis, Sample 378-1-2, 80 $\mathrm{cm}, 557 \mu \mathrm{m}$.

Siphonina reticulata, Sample $373 \mathrm{~A}-2-1,125 \mathrm{~cm}, 435 \mu \mathrm{m}$.

S. tubulosa, Sample 372-13-6, $120 \mathrm{çm}$, $145 \mu \mathrm{m}$. 

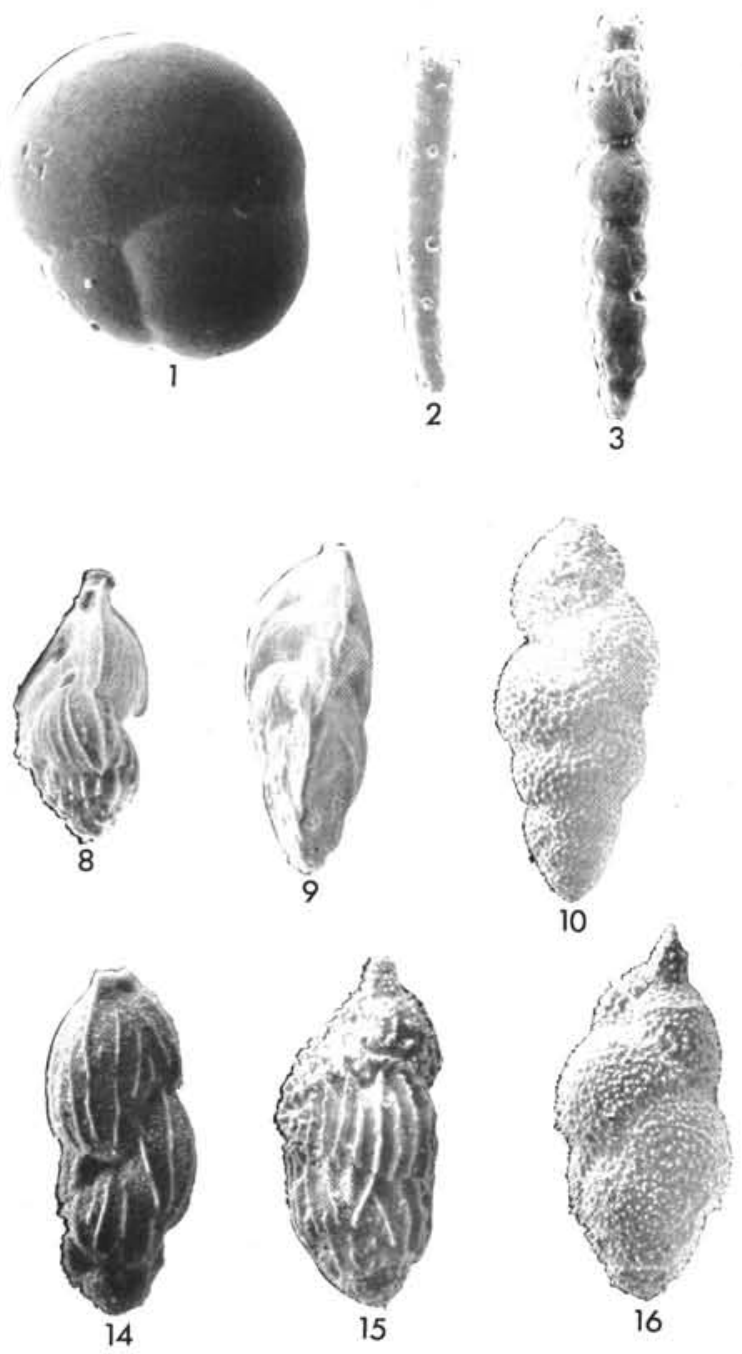

Figure 1

Sphaeroidina bulloides, Sample 378-1, CC, $292 \mu \mathrm{m}$.

Figure 2

Figures 3, 4

Stilostomella cf. annulifera, Sample $372-13-5,120 \mathrm{~cm}, 470 \mu \mathrm{m}$.

S. antillea.

3. Sample $372-38-4,75 \mathrm{~cm}, 312 \mu \mathrm{m}$.

4. Sample 372-13-6, $120 \mathrm{~cm}, 319 \mu \mathrm{m}$.

Figure 5

S. lepidula, Sample $372-13-3,80 \mathrm{~cm}$, $853 \mu \mathrm{m}$.

Figure 6 Trifarina angulosa angulosa, Sample 378-1, CC, $490 \mu \mathrm{m}$.

Figures 7, 8 T. angulosa pauperata, Sample 372-4-2, $60 \mathrm{~cm}$.

7. $155 \mu \mathrm{m}$.

8. $230 \mu \mathrm{m}$.

Figure $9 \quad T$. bradyi, Sample 372-13-2, $20 \mathrm{~cm}, 354$ $\mu \mathrm{m}$.

Figure 10 Uvigerina auberiana, Sample 372-3-3, $62 \mathrm{~cm}, 1304 \mu \mathrm{m}$.
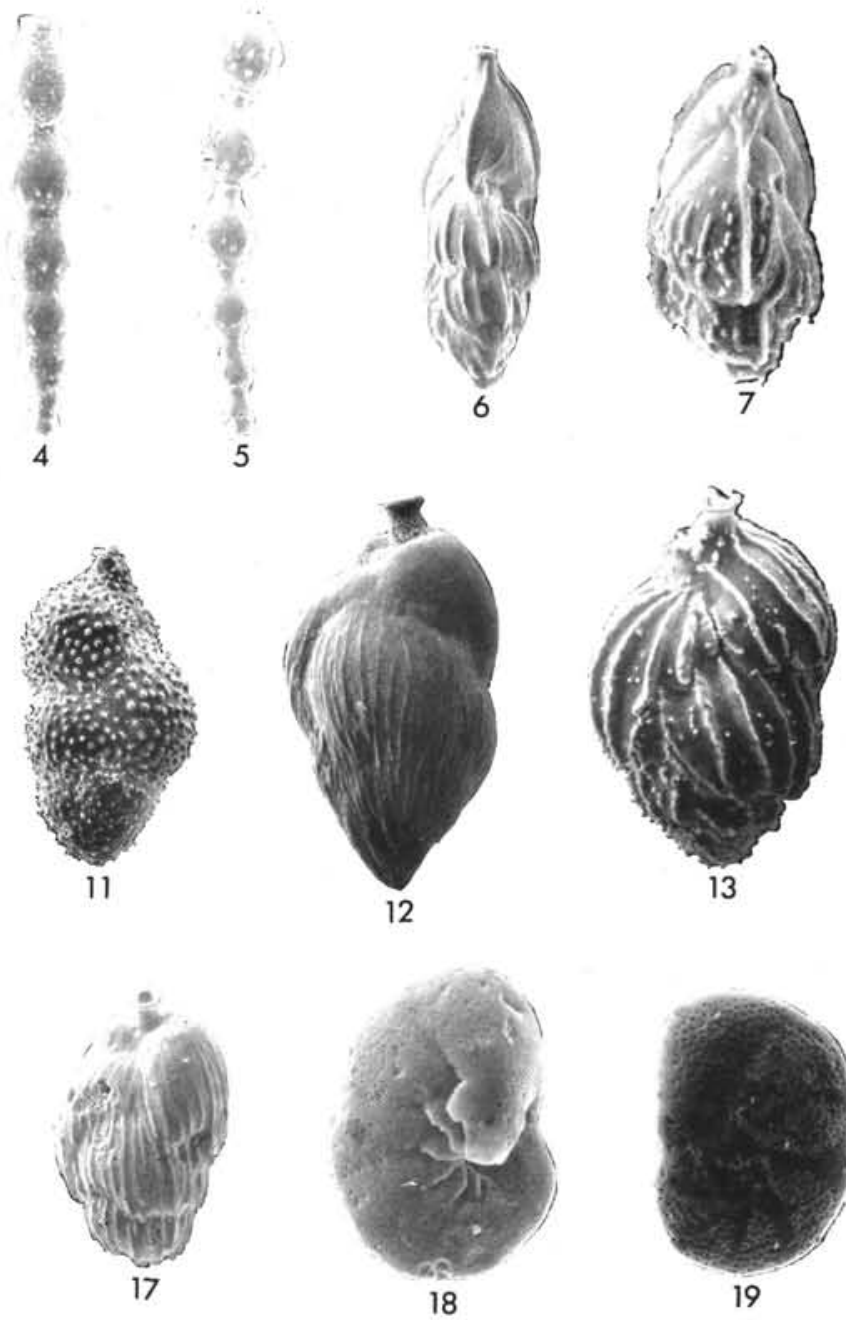

18

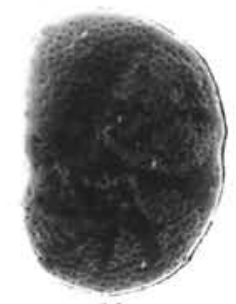

19
Figure 11

Figure 12

Figure 13

Figure 14

Figure 15

Figure 16

Figure 17

Figure 18

Figure 19

U. hispida, Sample 372-12, CC, 484 $\mu \mathrm{m}$.

U. longistriata, Sample 372-11, CC, $718 \mu \mathrm{m}$.

U. mediterranea, Sample 378-11-4, 110 $\mathrm{cm}, 344 \mu \mathrm{m}$.

$U$. mioindex, Sample 372-4-1, $128 \mathrm{~cm}$, $180 \mu \mathrm{m}$.

U. peregrina dirupta, Sample 378-1-2, $80 \mathrm{~cm}, 639 \mu \mathrm{m}$.

U. proboscidea, Sample 372-4-2, 90 $\mathrm{cm}, 480 \mu \mathrm{m}$.

U. rutila, Sample 372-12, CC, $360 \mu \mathrm{m}$. Valvulineria complanata, Sample $371-4-3,110 \mathrm{~cm}, 290 \mu \mathrm{m}$.

$V$. complanata, Sample 371-4-3, 110 $\mathrm{cm}, 271 \mu \mathrm{m}$. 